\title{
Carbonatites and Alkaline Igneous Rocks in Post-Collisional Settings: Storehouses of Rare Earth Elements
}

\author{
Kathryn M. Goodenough ${ }^{\left({ }^{*}{ }^{1}\right.}$, Eimear A. Deady ${ }^{1}$, Charles D. Beard ${ }^{1,2}$, Sam Broom-Fendley $^{3}$, \\ Holly A. L. Elliott ${ }^{3,4}$, Frederick van den Berg ${ }^{3}$, Hüseyin Öztürk ${ }^{5}$ \\ 1. British Geological Survey, the Lyell Centre, Edinburgh EH14 4AP, UK \\ 2. Institut des Sciences de la Terre, Université Grenoble Alpes, 38610 Gières, France \\ 3. Camborne School of Mines, University of Exeter, Penryn Campus, Penryn TR10 9FE, UK \\ 4. School of Environmental Sciences, University of Derby, Derby, UK \\ 5. Department of Geological Engineering, Istanbul University-Cerrahpaşa, Avcllar Campus, 34320 Avcılar Istanbul, Turkey \\ (iD)Kathryn M. Goodenough: https://orcid.org/0000-0001-5912-4831
}

\begin{abstract}
The rare earth elements (REE) are critical raw materials for much of modern technology, particularly renewable energy infrastructure and electric vehicles that are vital for the energy transition. Many of the world's largest REE deposits occur in alkaline rocks and carbonatites, which are found in intracontinental, rift-related settings, and also in syn- to post-collisional settings. Post-collisional settings host significant REE deposits, such as those of the Mianning-Dechang belt in China. This paper reviews REE mineralization in syn- to post-collisional alkaline-carbonatite complexes worldwide, in order to demonstrate some of the key physical and chemical features of these deposits. We use three examples, in Scotland, Namibia, and Turkey, to illustrate the structure of these systems. We review published geochemical data and use these to build up a broad model for the REE mineral system in post-collisional alkaline-carbonatite complexes. It is evident that immiscibility of carbonate-rich magmas and fluids plays an important part in generating mineralization in these settings, with REE, Ba and $F$ partitioning into the carbonate-rich phase. The most significant REE mineralization in post-collisional alkaline-carbonatite complexes occurs in shallow-level, carbothermal or carbonatite intrusions, but deeper carbonatite bodies and associated alteration zones may also have REE enrichment.
\end{abstract}

KEY WORDS: post-collisional, alkaline, carbonatite, rare earth elements, tectonics, carbon cycle.

\section{INTRODUCTION}

In recent years, the importance of the rare earth elements (REE) for modern technologies has led to an increased research focus on alkaline rocks and carbonatites (Dostal, 2017; Smith et al., 2016; Chakhmouradian and Zaitsev, 2012). The REEs are critical for many modern technologies, particularly for the permanent magnets used in the generators of wind turbines and the motors of electric vehicles (Goodenough et al., 2018). Hence it is vital to understand the processes by which they are concentrated and trapped in the crust.

Alkaline silicate and carbonatite complexes occur not just in continental rifts, but also in syn- to post-collisional tectonic settings, and many significant REE deposits are associated with such complexes in these settings (Jung et al., 2020a; Liu and Hou, 2017). The term 'syn-collisional magmatism' is used to refer to magmas emplaced during the peak of a collisional event (Song et al., 2015). Most such magmas are crustally-derived, but rare

*Corresponding authors: kmgo@bgs.ac.uk

(C) British Geological Survey, UKRI 2022

Manuscript received December 19, 2020.

Manuscript accepted June 22, 2021. examples of mantle-derived alkaline compositions have been described (Jung et al., 2020a). The term 'post-collisional magmatism' is widely used in the literature but is only loosely defined (Couzinié et al., 2016; Chung et al., 2005; Bonin, 2004; Chen and Jahn, 2004). In this contribution, we define post-collisional magmatism as occurring in collisional belts, but typically associated with transcurrent displacement along major trans-crustal shear zones, in what has been described as a period of crustal relaxation after the main collision (Couzinié et al., 2016; Song et al., 2015; Bonin, 2004; Liégeois et al., 1998). Such magmatism generally post-dates the peak of the main collisional event (as recorded by metamorphic mineral assemblages) by millions to tens of millions of years (Couzinié et al., 2016; Sylvester, 1989). The source of post-collisional magmas has been widely debated, with lower crust, metasomatized lithospheric mantle and asthenospheric mantle all being considered. Both slab break-off and lithospheric delamination have been proposed as triggers for melting (Freeburn et al., 2017; Dilek and Altunkaynak, 2009; Guo et al., 2006).

Post-collisional magmatic suites may be voluminous, and are commonly granite-dominated (Liégeois et al., 1998). The earlier parts of the suite are typically characterized by high-K calcalkaline compositions, and there is a transition with time to alkaline compositions including highly potassic syenite and monzonite

Goodenough, K. M., Deady, E. A., Beard, C. D., et al., 2021. Carbonatites and Alkaline Igneous Rocks in Post-Collisional Settings: Storehouses of Rare Earth Elements. Journal of Earth Science, 32(6): 1332-1358. https://doi.org/10.1007/s12583-021-1500-5. http://en.earth-science.net 
(Padilha et al., 2019; Liégeois et al., 1998). Granite is the most common rock type of post-collisional magmatic suites, but the alkaline end of the magmatic spectrum is more commonly represented by syenitic lithologies. In less deeply-eroded belts, the corresponding volcanic lithologies may be present. These alkaline magmatic compositions are typically relatively enriched in $\mathrm{Sr}, \mathrm{Ba}$, and the light rare earth elements (LREE) but relatively depleted in $\mathrm{Rb}, \mathrm{Nb}, \mathrm{Ta}$, and the heavy rare earth elements (HREE), when compared with other granitoid associations (Fowler et al., 2008). Mafic rocks typically occur in smaller volumes than felsic lithologies, and magma mingling features are common (Bonin, 2004). Although volumetrically minor, carbonatites represent a common component within post-collisional magmatic suites (Veevers, 2007). Mitchell (2005) coined the term 'carbothermal residua' for those carbonatites associated with potassic alkaline igneous rocks, and proposed that they are derived from a source in metasomatized lithospheric mantle.

Post-collisional, alkaline, potassic magmatic suites are widely recognized to be associated with economic mineralization of a range of metals. In particular, copper-gold porphyry, iron oxide-copper-gold (IOCG) and epithermal gold mineralization are known from these magmatic systems (Holwell et al., 2019; Richards and Mumin, 2013; Kelley and Ludington, 2002). There is general agreement that the source of metals lies in the metasomatized sub-continental lithospheric mantle (Holwell et al., 2019; Hronsky et al., 2012). In recent years, it has also been recognized that post-collisional alkaline-carbonatite magmatic systems host many of the world's major REE deposits (Liu and Hou, 2017; Poletti et al., 2016).

In this contribution, we review global examples of postcollisional alkaline-carbonatite mineral systems that host REE deposits. We discuss constraints on the composition of their melt source regions, the tectonic and structural setting of their emplacement, and the igneous and hydrothermal processes that redistributed, concentrated and trapped the REE.

\section{OVERVIEW OF REE MINERALIZATION ASSOCIA- TED WITH ALKALINE \& CARBONATITE MAGMATISM IN POST-COLLISIONAL SETTINGS}

Post-collisional alkaline magmatic suites are known worldwide (Fig. 1) and have formed throughout much of geological history, from the Neoarchean to the present day (Fig. 2). In this section we provide an overview of some of the major examples that are known to be associated with REE mineralization. The following section focuses on some well-characterized case studies and develops a model for REE mineralization in these examples.

\subsection{Archean}

There are few examples of alkaline and carbonatite magmatism in the Archean. The best-documented examples are from cratonic areas around the North Atlantic, including potassic alkaline volcanic rocks in the Abitibi belt of Canada and the syenitic rocks of the Skjoldungen Province in Greenland (Blichert-Toft et al., 1996). All show the typical geochemical characteristics of post-collisional magmatic suites, but economic concentrations of the REE have thus far not been identified. The most significant carbonatite of this age is the Siilinjarvi carbonatite in Finland, which is mined for phosphate but has the potential to produce REE as a by-product (Decrée et al., 2020; O’Brien et al., 2015; Al-Ani, 2013).

\subsection{Paleoproterozoic}

The Paleoproterozoic was a period of continental collision and reorganization associated with the development of the Columbia/Nuna supercontinent, which was fully assembled by around $1800 \mathrm{Ma}$ (Evans and Mitchell, 2011). Amalgamation of this supercontinent formed a global network of orogenic belts (Meert, 2012), with extensive development of base and precious metal deposits (Pehrsson et al., 2016). Post-collisional magmatism, dominated by granitoid plutons, is common along many of these belts (Ivanov et al., 2019; Oh et al., 2019;

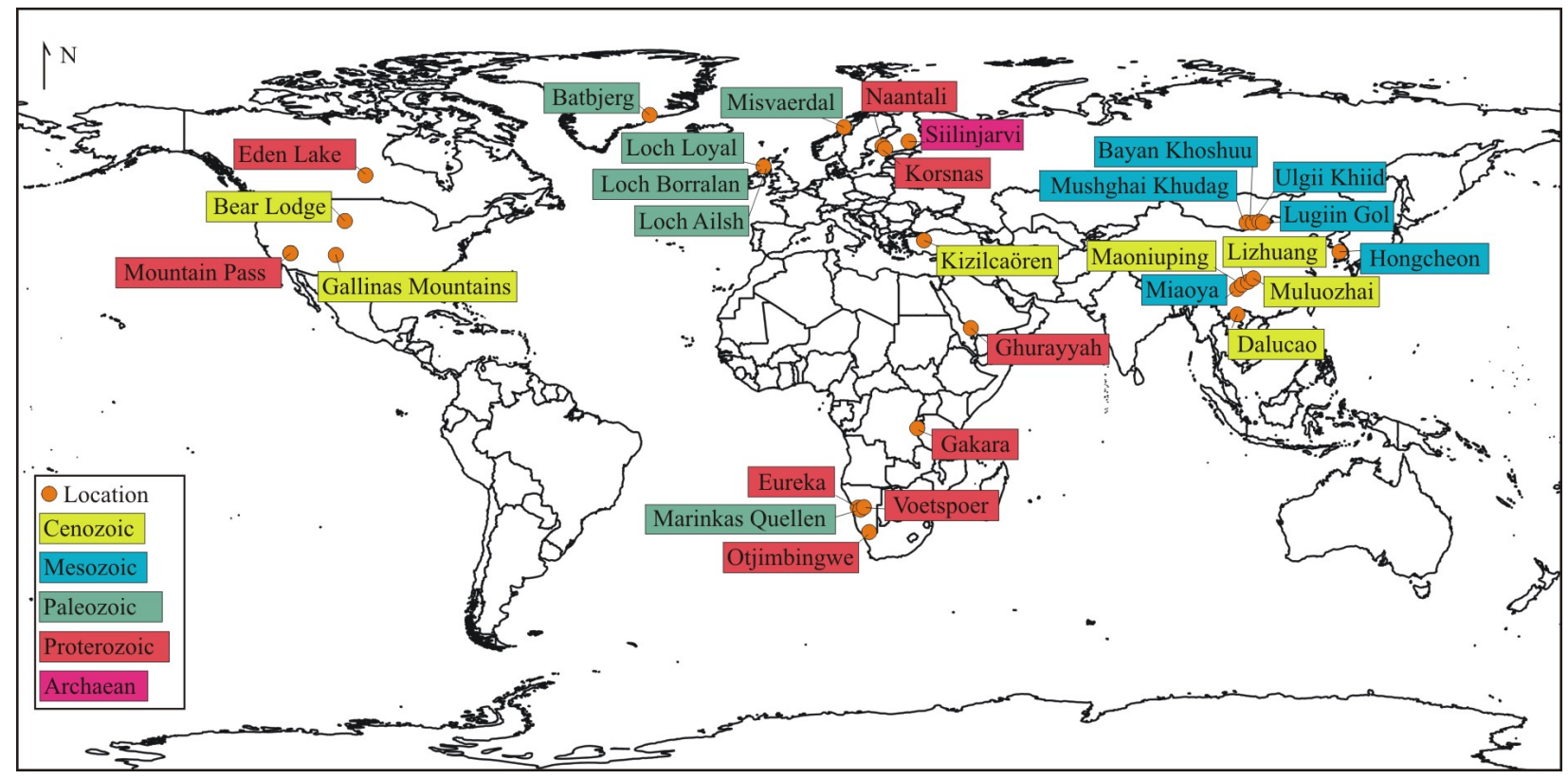

Figure 1. Global map showing the locations of post-collisional alkaline-carbonatite complexes mentioned in the text. 


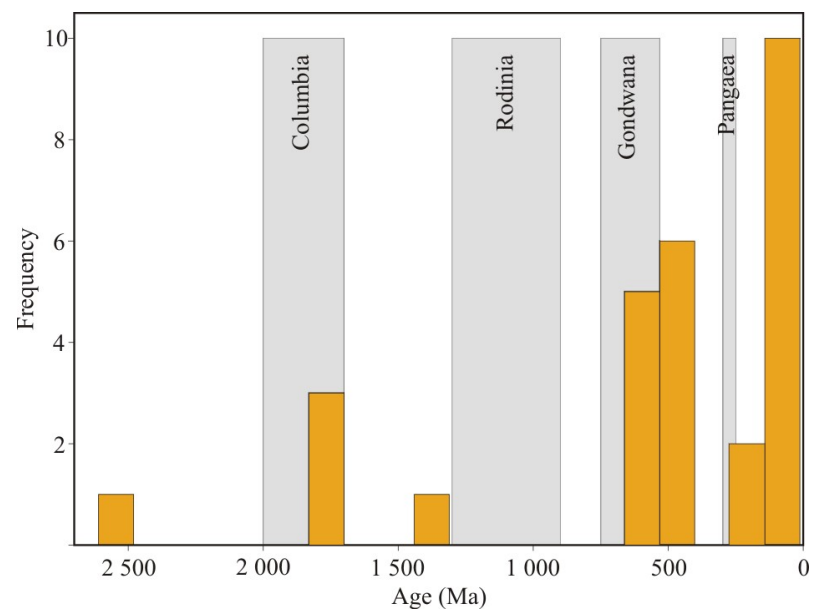

Figure 2. Age distribution of post-collisional alkaline-carbonatite complexes mentioned in the text, overlaid on supercontinent assembly timelines, based on the 'Timeline B' assembly time of Gardiner et al., (2016). Ages for postcollisional alkaline-carbonatite complexes are from references cited in the text.

Whalen et al., 2010). The most important REE deposit of this age is the ca. 1400 Ma carbonatite at Mountain Pass in California, which hosts bastnäsite, monazite and barite mineralization, and has been mined sporadically for REE since 1954 (Castor, 2008). The carbonatite is associated with ultrapotassic post-collisional granitoids, and although there is some debate about the tectonic setting into which it was emplaced, this association suggests that the Mountain Pass carbonatite is also post-collisional in nature (Poletti et al., 2016). Post-collisional carbonatites and alkaline rocks, such as the Naantali and Korsnäs carbonatites in Finland, are common in the Svecofennian Belt of Scandinavia (Al-Ani et al., 2018; Goodenough et al., 2016; Woodard and Hetherington, 2014; Al-Ani, 2013; Sarapää et al., 2013). These lithologies are typically enriched in $\mathrm{Ba}, \mathrm{Sr}$ and the LREE but poor in $\mathrm{Nb}$.

In the trans-Hudson Orogen of Canada, the Eden Lake Complex shows many typical features of a post-collisional alkaline-carbonatite complex; it comprises syenitic and carbonatitic lithologies with REE-enriched pegmatitic veins and segregations containing aegirine-augite, apatite, britholite, allanite, titanite, and fluorite (Chakhmouradian et al., 2008; Arden and Halden, 1999; Halden and Fryer, 1999).

\subsection{Neoproterozoic to Paleozoic}

Assembly of the main Neoproterozoic supercontinent, Rodinia, was associated with significantly less post-collisional alkaline magmatism (Liu C et al., 2019). The next major period of post-collisional alkaline magmatism occurred from the end of the Proterozoic into the Cambrian, and was associated with the amalgamation of Gondwana (Bonin, 2007). Post-collisional granitoids are common in the Pan-African-Brasiliano orogenic belts formed at this time, with late alkaline magmatism also present in several of these belts (Küster and Harms, 1998; Black et al., 1985). A number of potential REE deposits are associated with alkaline magmatism formed during this period. The only currently producing REE deposit associated with the Pan-African belts is the ca. $600 \mathrm{Ma}$ bastnäsite carbonatite-related deposit at Gakara in Burundi (Buyse et al., 2020; Ntiharirizwa et al., 2018), which is slightly older than the main phase of post-collisional magmatism. In Namibia, voluminous granitoid plutons and several alkaline complexes are associated with the Damara Orogen, which is a Pan-African collisional belt (Lehmann et al., 2016). Relatively rare gabbroic, dioritic and granitic intrusions were emplaced during the period of continental collision from ca. 580 to $550 \mathrm{Ma}$ (Jung et al., 2020b; Milani et al., 2015; Miller, 2008). Shortly thereafter, between $\sim 550-540 \mathrm{Ma}$, alkaline complexes were emplaced along zones of structural weakness. These alkaline complexes include the ca. 545 Ma Otjimbingwe Alkaline Complex (Jung et al., 2020a), the 548 \pm 4 Ma Eureka carbonatite REE prospect (Broom-Fendley et al., 2020; Gonçalves et al., 2018; Dunai et al., 1989), and the ca. 540 Ma Voetspoer syenite (Jung et al., 2005). These are considered to be syn-collisional, and to have been emplaced into a trans-tensional setting within an orogenic belt associated with flat subduction (Jung et al., 2020a). Further south in Namibia, the post-collisional, ca. 550-490 Ma Kuboos-Bremen Igneous Province includes the Marinkas Quellen carbonatite, which contains REE-enriched ferrocarbonatite dykes (Smithies and Marsh, 1998; Allsopp et al., 1979). Another significant area of post-collisional alkaline magmatism formed at this time lies in the Arabian-Nubian Shield, where peralkaline granitic plutons are common (Be'eri-Shlevin et al., 2009), including the rare-metal enriched Ghurayyah pluton (Dostal, 2017; Küster, 2009).

In Europe and North America, the Caledonian-Appalachian Orogenic Belt represents the suture of the Iapetus Ocean, closed during Ordovician to Silurian continental collision. Postcollisional alkaline magmatism with localized REE enrichment is known from several localities, including the Loch Loyal and Loch Borralan complexes in Northwest Scotland, Misværdal in Norway and Batbjerg in Greenland (Goodenough et al., 2016; Ihlen et al., 2014). The Northwest Scotland examples are discussed in more detail in the following section.

\subsection{Mesozoic}

Many of the most important REE deposits associated with post-collisional alkaline-carbonatite magmatism occur in Asia. Some of the earliest examples are associated with Triassic collision between the North China Craton and South China Craton (Kim et al., 2006). Post-collisional magmatism dating from this time includes potassic to ultrapotassic intrusions in South Korea (Peng et al., 2008). These are associated with the REE-enriched Hongcheon carbonatite dykes, which contain monazite, apatite, strontianite, barite and pyrite (Kim et al., 2016). In China, the REE mineralization in the Miaoya carbonatite was also formed at this time (Çimen et al., 2018; Ying et al., 2017).

The Central Asian Orogenic Belt lies between the Siberian Craton to the north, the China Craton to the southeast, and the Himalayan Orogenic Belt to the south. It represents a collage of largely Precambrian microcontinental fragments and accretionary belts, originally assembled as part of Gondwana and then reorganized during the Paleozoic (Zhou et al., 2018). The final collisional event in this region was the Late Jurassic to Early Cretaceous closure of the Mongol-Okhotsk Ocean (Yang et al., 2015). This event was associated with a transition from subductionrelated, through post-collisional to extensional magmatism 
(Wang et al., 2015). Numerous alkaline-carbonatite complexes were formed at this time (Nikiforov and Yarmolyuk, 2019), of which the most important are those in southern Mongolia, including the Mushghai Khudag, Bayan Khoshuu and Ulgii Khiid complexes, all of which are REE-enriched (Nikolenko et al., 2020, 2018; Baatar et al., 2013). These complexes have commonly been described as rift-related, but several features, including enrichment in $\mathrm{Ba}, \mathrm{Sr}, \mathrm{F}, \mathrm{K}$ and the LREE, are consistent with derivation from a mantle source that has been affected by subduction (Feng et al., 2020; Nikolenko et al., 2020).

\subsection{Cenozoic}

The Mesozoic to Cenozoic Tethyan-Himalayan Orogen, stretching from southern Europe to southern China, represents one of the world's major collisional belts and also a major metallogenic province (Hou and Zhang, 2015; Richards, 2015). Post-collisional alkaline-carbonatite magmatism is common, and in many cases hosts significant REE deposits. In the Turkish part of the belt, a series of continental blocks collided through the Cretaceous and Cenozoic, and this was associated with two significant periods of post-collisional, ultrapotassic magmatism, one of Eocene to Early Miocene age, and the second in the Middle Miocene (Prelević et al., 2012; Dilek and Altunkaynak, 2007). Further east, Eocene to Oligocene alkaline magmatism was also common (Sokół et al., 2018). The most significant REE deposit formed at this time was the Oligocene alkaline-carbonatite Kizilcaören Deposit in Turkey (Öztürk et al., 2019; Nikiforov et al., 2014). In southern Turkey, postcollisional, ultrapotassic volcanism has occurred during the Pliocene and Quaternary (Prelević et al., 2012). Erosion levels in this area are too shallow for any magmatic REE deposits to be recognized, but exploration has been undertaken in REE placer deposits which are considered to have a volcanic source (Deady et al., 2019). The LREE-enriched Khanneshin Carbonatite Complex in Afghanistan (Tucker et al., 2012) may also be post-collisional in nature.

The most economically important REE mineralization associated with post-collisional alkaline and carbonatite complexes occurs in the Mianning-Dechang belt of China, in the eastern part of the Himalayan Orogen (Liu and Hou, 2017; Hou et al., 2009, 2006). This very well-studied belt, which can be considered as the type area for post-collisional alkaline-carbonatite systems, includes the ca. 12-27 Ma Maoniuping, Lizhuang, Muluozhai and Dalucao REE deposits (Liu et al., 2015; Xu et al., 2012, 2008, 2003; Wang et al., 2001). These deposits occur as veins, lenses and breccias of barite-fluorite-bastnäsite-calcite ore with a range of alkaline silicate minerals (Xie et al., 2015; Hou et al., 2009). They are associated with syenite-carbonatite complexes that were emplaced during post-collisional shearing on regional strike-slip faults (Hou et al., 2009). They are widely considered to have been derived from a mantle source that was enriched by fluids released from marine sediments carried on a subducting slab (Jia and Liu, 2020; Guo and Liu, 2019; Hou et al., 2015). Similar REE deposits occur at Nam Xe in Vietnam, where ca. $30 \mathrm{Ma}$ carbonatite dykes contain calcite, aegirine, biotite, arfvedsonite, magnetite, apatite, monazite, sulphides and REE-fluorcarbonates (Thi et al., 2014).

In the USA, Cenozoic post-collisional alkaline magmatic complexes were emplaced towards the end of the Laramide Orogeny, and host several REE deposits (McLemore, 2018). These include the Gallinas Mountains of central New Mexico, which contain Cenozoic, syn- to post-collisional alkaline intrusives with associated REE deposits in breccia pipes and fault-hosted breccias. The REE deposits comprise the fluoritebastnäsite-barite-calcite-quartz breccia matrices (Williams-Jones et al., 2000). The Bear Lodge REE deposit in Wyoming is also hosted in an alkaline-carbonatite complex within this belt. The most heavily-explored part of the deposit is in the Bull Hill diatreme, comprising a breccia pipe with a stockwork of carbonatite veins and dykes; REE mineralization is related to multiple phases of carbo-hydrothermal activity within this diatreme (Moore et al., 2015). Carbonatite dykes and veins extend throughout much of the alkaline complex, and some peripheral zones are HREEenriched (Andersen et al., 2016).

Some of the youngest post-collisional alkaline magmatism known occurs in Italy, in the Pliocene-Quaternary Roman Magmatic Province (Bianchini et al., 2008). This province is volumetrically dominated by silica undersaturated ultrapotassic lavas and volcaniclastic rocks of tephrite to phonolite composition (Mollo and Vona, 2014). Recent work has indicated the presence of subvolcanic carbonatites in this area, with high contents of Ba, Sr, LREE and F (Stoppa et al., 2019). Silicate lava flows also contain magmatic calcite, interpreted to originate from carbonate melts, although these have been interpreted as representing reworked crustal material rather than mantlederived carbonatites (Gozzi et al., 2014).

\section{BUILDING A REE DEPOSIT MODEL FOR POST- COLLISIONAL SETTINGS: CASE STUDIES}

It is rare to find a single post-collisional alkaline-carbonatite complex that is exposed in such a way as to allow study of the vertical relationships between the magmatic plumbing system and near-surface zones of volcanic rocks and hydrothermal alteration. Here we describe three case-studies, from Turkey, Namibia and Scotland, which represent different erosion levels of post-collisional alkaline-carbonatite systems. The Oligocene Kizilcaören Complex in Turkey represents a REE prospect that was emplaced at shallow levels, $<<1 \mathrm{~km}$ from the surface (Stumpfl and Kirikoglu, 1985). The deeper levels of a post-collisional alkaline magmatic system, with larger intrusions containing mafic cumulates, are represented by the ultrapotassic alkaline complexes of Silurian age in NW Scotland, which were probably emplaced at depths in the range 4-8 km (Holdsworth et al., 1999). The emplacement depth of the Eureka carbonatite REE prospect in Namibia, formed in the Latest Neoproterozoic, is uncertain but it may reflect levels between the deeper cumulate-bearing intrusions and the subvolcanic system. In the following sections, the rock-types and structure of these casestudies are outlined in more detail, using information from the literature combined with our new field observations, in order to develop a generalized model for these post-collisional alkalinecarbonatite REE mineral systems.

\subsection{Kizilcaören}

The alkaline igneous complex at Kizilcaören, located approximately $40 \mathrm{~km}$ from Eskişehir, Turkey (Fig. 3a), comprises 
lenses of banded fluorite-barite-carbonate ore with economic potential for REE, Ba and fluorspar, and with bastnäsite as the main REE mineral. The Mineral Research and Exploration Institute of Turkey carried out a drilling campaign in the 1970s and stated a reserve of $4.67 \mathrm{Mt}$ of $\mathrm{REE}(\mathrm{Ce}+\mathrm{La}+\mathrm{Nd}+\mathrm{Y})$ with an average grade of $2.78 \mathrm{wt} . \%$ as well as fluorite and barite resources (Öztürk et al., 2019; Gültekin et al., 2003). These figures may not meet modern-day requirements of a reserve. The complex is under licence to Etimaden, which completed a drilling campaign in 2014, but has not yet released updated resource or reserve data.

Kizilcaören lies within the North Anatolian shear zone, a crustal scale strike-slip structure that developed along accretionary structures within the Tethyan-Himalayan Orogen (Öztürk et al., 2019). During the Late Triassic, Paleozoic basement was overthrust from the south by a Permo-Triassic arc and related
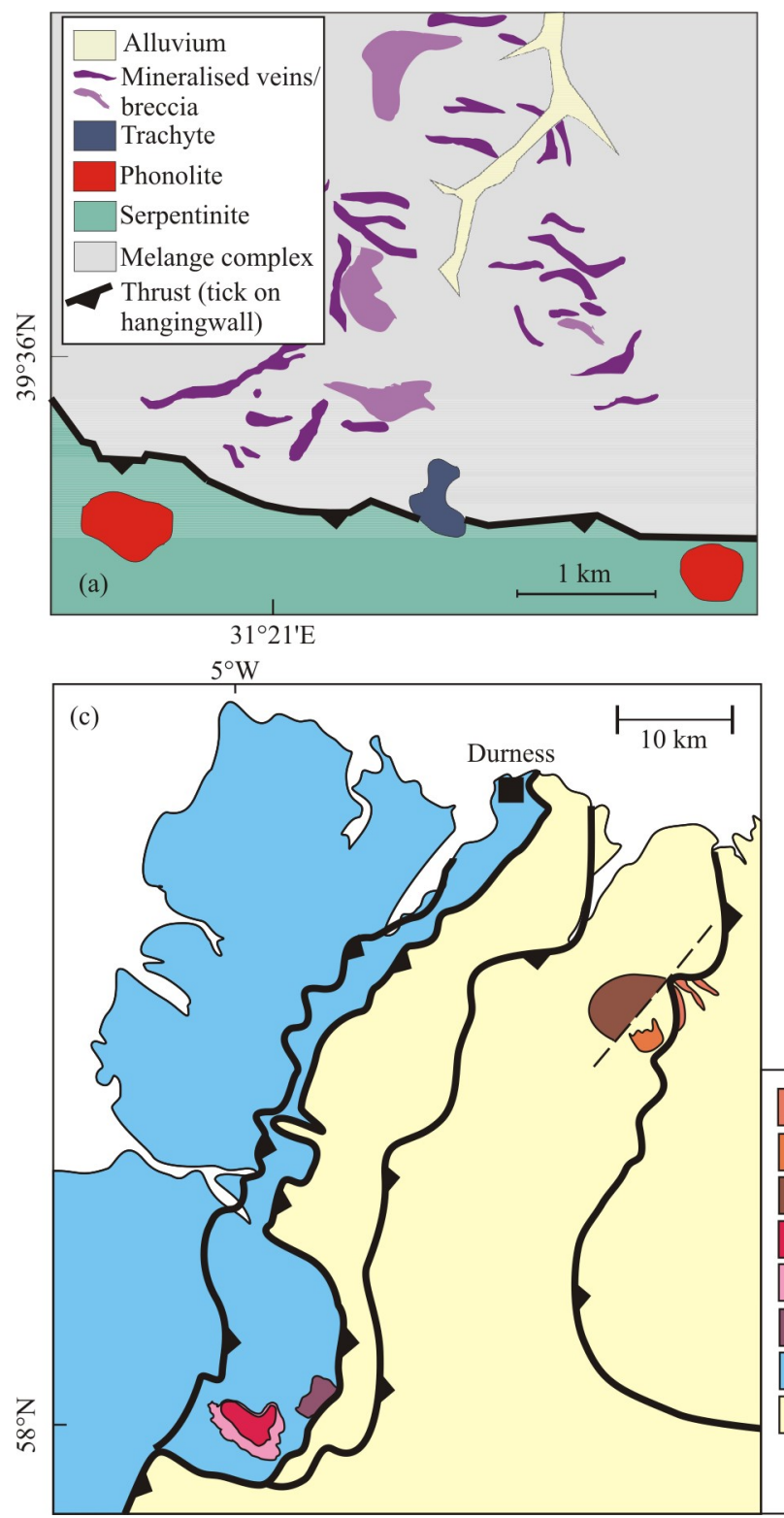

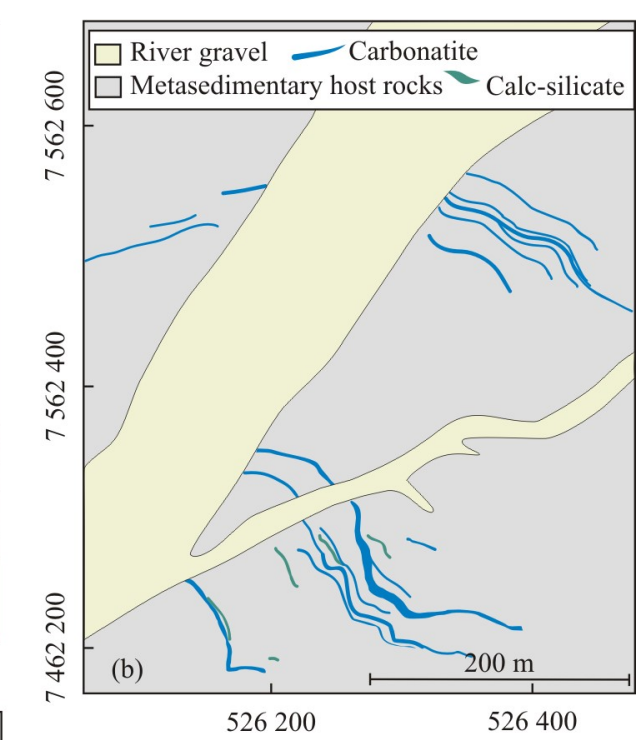
the south side (hanging wall) of the thrust (Fig. 3a) (Sarıfakıoğlu et al., 2009). The carbonatite and the ore bodies are emplaced

accretionary complexes of the Paleo-Tethys (Gültekin et al., 2003). Around Kizilcaören, this is represented by an accretionary wedge mélange complex which is separated from overlying serpentinized ultramafic rock by a major NW-SE trending thrust zone (Fig. 3a). Triassic to Jurassic deformed sedimentary and volcaniclastic rocks are the main constituents of the mélange complex (Öztürk et al., 2019; Gültekin et al., 2003). The Kizilcaören ore deposit is associated with alkaline porphyritic trachyte and phonolite, and carbonatite, emplaced along this reactivated thrust zone during the Oligocene (24-25 Ma) (Öztürk et al., 2019; Nikiforov et al., 2014; Gültekin et al., 2003; Hatzl, 1992; Stumpfl and Kirikoglu, 1985).

Three alkaline intrusions (two phonolite and one trachyte), forming stocks about $500 \mathrm{~m}$ in diameter, intrude serpentinite on 
into the brecciated mélange lithologies on the north side of the thrust (Nikiforov et al., 2014). True carbonatite is rarely exposed, and occurs as banded sills and dykes typically with lateral extents of only a few metres. It is coarse-grained and comprises $>90 \%$ calcite with phlogopite, apatite and possible pseudomorphs after pyrite and barite (Nikiforov et al., 2014). Some fenitized zones have been identified, but not mapped in detail.

The banded REE ore at Kizilcaören is typically hosted in tabular to lensoid, broadly horizontal, layered ore bodies which are up to tens of metres thick in places and tens to hundreds of metres in extent, with a total areal extent of approximately $4 \mathrm{~km}^{2}$. The ore comprises distinct bands of fluorite, barite and bastnäsite up to $20 \mathrm{~cm}$ thick, typically flat-lying to shallowly dipping (Fig. 4a). Rare vertical to sub-vertical 'feeder' veins of ore material, up to $5 \mathrm{~m}$ thick and $20 \mathrm{~m}$ in length, are also present. Localized barite-rich veins, a few cm thick, cross-cut the ore bodies (Öztürk et al., 2019). The contact between the ore bodies and the host metasedimentary rocks is sharp, and the host rocks are typically
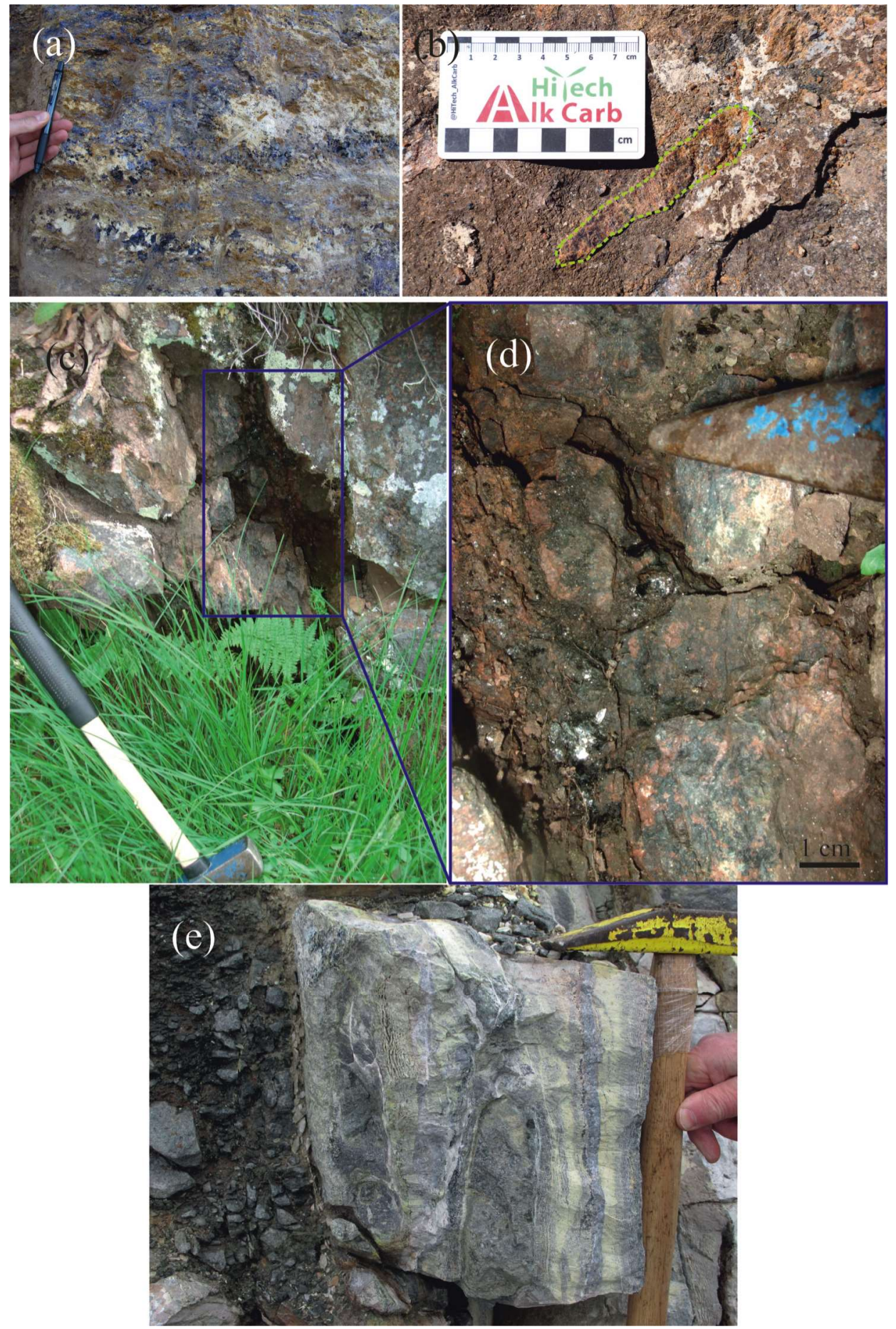

Figure 4. Field photographs of case study localities. (a) Banded barite-fluorite-bastnäsite ore at Kizilcaören; (b) large monazite in the Eureka carbonatite; (c) and (d) biotite-allanite-apatite-magnetite alteration veins in the Loch Loyal Complex; (e) remobilized, metasomatized host-rock carbonate in contact with pseudoleucite syenite at the Loch Borralan Complex. 


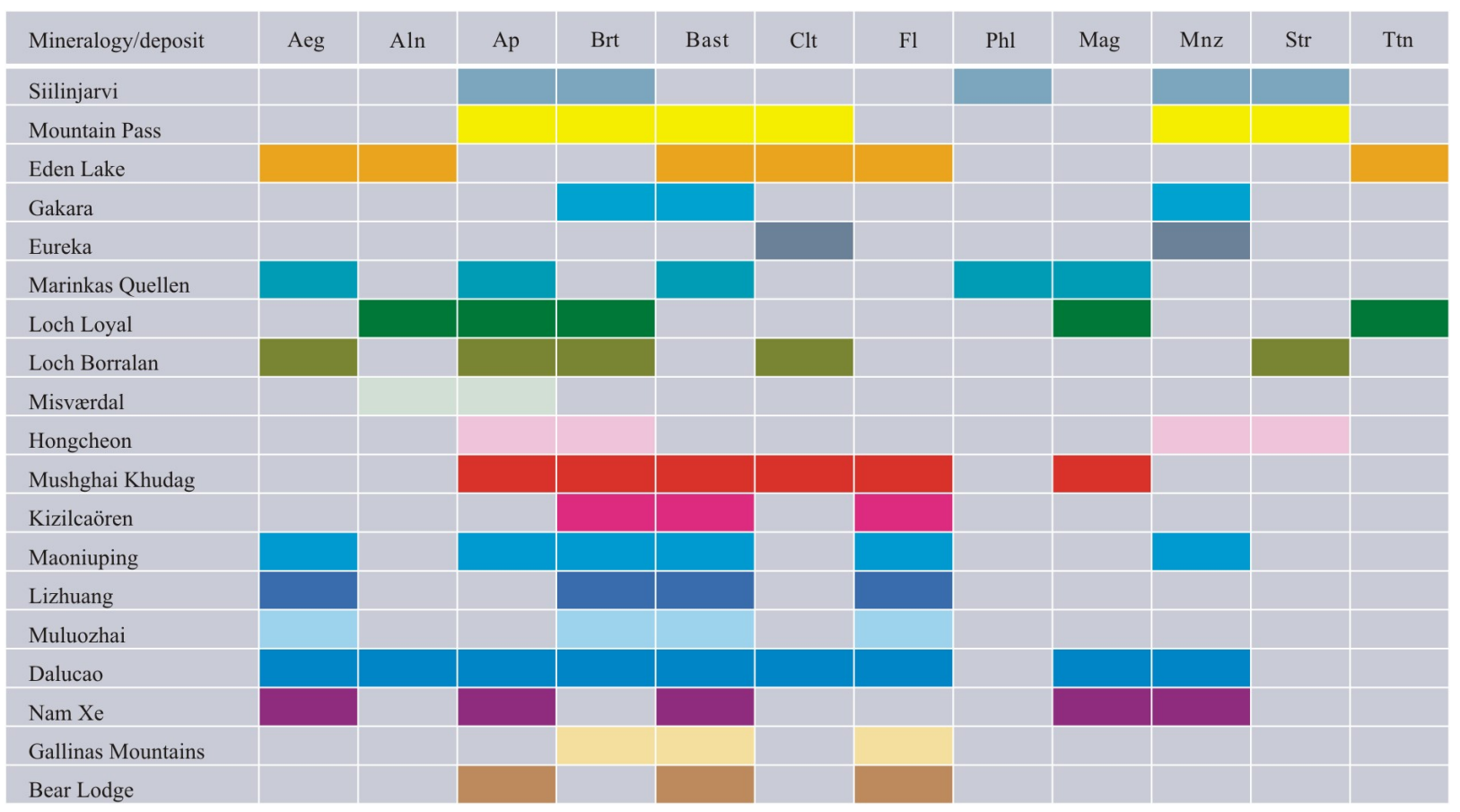

Figure 5. Characteristic mineralogy from selected alkaline-carbonatite complexes listed in the text. All details from references as provided in the text. Aeg. Aegirine; Aln. allanite; Ap. apatite; Brt. barite; Bast. bastnäsite; Clt. celestine; Fl. fluorite; Phl. phlogopite; Mag. magnetite; Mnz. monazite; Str. strontianite; Ttn. titanite. Abbreviations after Whitney and Evans (2010).

silicified and brecciated in a zone that extends several metres from the contact of the ore body. The region has undergone significant weathering and the upper parts of the ore bodies are dominated by manganese oxidation with lesser iron oxidation.

The ore body mineral assemblage and paragenesis has previously been described in detail by Stumpfl and Kirikoglu (1985), Gültekin et al. (2003), Nikiforov et al. (2014) and Öztürk et al. (2019). Isotopic analysis has demonstrated that the ore is directly related to mantle-derived carbonatite (Çimen et al., 2020). The ore is dominated by fluorite, barite, and bastnäsite with quartz, calcite, phlogopite, pyrite, and locally pyrochlore (Fig. 5). Minor plagioclase, monazite, strontianite, and rutile have also been observed. Broadly, there appear to have been two phases of crystallization: an early fluorite-baritephlogopite phase and a later carbonate-dominated phase. Subsequently, recent supergene alteration led to dissolution and oxidation of primary $\mathrm{Mn}-$, Fe- and Ca-carbonate minerals, with the ore becoming porous and rich in iron-manganese oxides (Nikiforov et al., 2014). Minerals such as brockite and florencite also formed at this time.

\subsection{Eureka}

The Eureka Carbonatite Complex is located approximately $35 \mathrm{~km}$ west of Usakos, Namibia, and comprises a swarm of dolomite-carbonatite dykes emplaced into the southern central zone of the Damara belt (Broom-Fendley et al., 2020; Dunai, 1989; von Knorring and Clifford, 1960). This zone is typified by low-pressure high-temperature metamorphism, ranging up to granulite facies (Jung et al., 2019; Longridge et al., 2017). $\mathrm{U}-\mathrm{Pb}$ dating of the monazite in the carbonatite gives an age of $548 \pm 4 \mathrm{Ma}$, which is interpreted as dating intrusion of the carbonatite (Gonçalves et al., 2018). This age is just prior to peak metamorphic conditions in the southern central zone, which occurred between 550-500 Ma (Jung et al., 2019; Longridge et al., 2017; Jung and Mezger, 2003), suggesting that Eureka is a 'syn-collisional' carbonatite. Eureka is close to the intersection of the Omaruru and Welwitschia lineaments, which represent large scale regional shear zones (Corner, 2008), and may have provided a conduit for the emplacement of carbonatite melt during orogenesis.

The dykes are principally composed of coarse (1-2 mm) dolomite, with a variable abundance of monazite (typically $\sim 1$ $\mathrm{mm}$ to $7 \mathrm{~cm}$, but up to $25 \mathrm{~cm}$; Fig. 4b), magnetite, graphite, calcite, hematite and minor quartz. The dykes are up to $7 \mathrm{~m}$ thick, but typically 1-2 m, with extensive additional disseminated veins (of $<1 \mathrm{~m}$ in thickness) of the same material occurring across a wide area (Fig. 3b). Monazite is the main ore mineral, and REE exploration is on-going at Eureka with an initial inferred resource of $0.31 \mathrm{Mt}$ grading at $4.8 \%$ TREO (total rare earth oxides), at a cut-off grade of $1.3 \%$ TREO. The project is under licence to E-Tech Resources.

The carbonatite dykes at Eureka are emplaced into Neoproterozoic feldspar-bearing quartzite, graphitic schist and calc-silicate rocks. New mapping, based on exploration drilling and trenching (Fig. 3b), demonstrates that the carbonatite dykes are broadly parallel to the local steeply dipping foliation in the calc-silicate rocks. However, there is evidence that small-scale carbonatite veins cross-cut the country rock units, ruling out the possibility that the rocks represent metamorphosed extrusive carbonatite or that they were emplaced prior to any deformation. Moreover, the dykes are surrounded by a thin selvage of skarn, composed of diopside, actinolite, monazite, apatite, graphite and minor allanite, interpreted as a reaction between the carbonatite and the host rocks. Classic fenitization appears to be 
absent, although Dunai (1989) reported replacement textures in the country rock, where feldspars are overgrown and replaced by orthoclase, up to $20 \mathrm{~m}$ from carbonatite dykes. $\mathrm{A}^{87} \mathrm{Sr} /{ }^{86} \mathrm{Sr}$ isotope study supports a mantle origin for the dykes, with minor crustal input (Dunai et al., 1989).

\subsection{NW Scotland}

An excellent example of the deeper levels of a postcollisional alkaline suite is provided by the ultrapotassic alkaline igneous complexes of Northwest Scotland. These intrusions are Silurian in age and were emplaced into a major thrust zone, formed during the Scandian Event of the Caledonian Orogeny. Field relationships show that the alkaline magmatism temporally overlapped the thrust-related deformation, indicating that these intrusions are late syn- to post-collisional. Three major ultrapotassic, post-collisional intrusive complexes are recognized: the Loch Borralan and Loch Ailsh plutons, and the Loch Loyal Syenite Complex (Thompson and Fowler, 1986). The depth of emplacement of these plutons is not well-constrained, but is generally considered to be of the order of a few (no more than 10) kilometres (Holdsworth et al., 1999). Geochemical studies have indicated that they were derived from an enriched mantle source, potentially metasomatized by fluids with a source in subducted sediment (Fowler et al., 2008; Thirlwall and Burnard, 1990).

The Loch Ailsh pluton is dated at $430.6 \pm 0.3 \mathrm{Ma}$ (Goodenough et al., 2011) and largely comprises leucocratic alkali feldspar-syenites (Parsons, 1965) with some marginal ultramafic rocks. The ultramafic rocks include pyroxenites and amphibolites, typically rich in magnetite, phlogopite, titanite and apatite, with chalcopyrite and pyrite (Styles et al., 2004). Post-emplacement deformation means that the threedimensional structure of the Loch Ailsh pluton is the least understood of the three intrusive complexes.

The Loch Borralan pluton comprises two intrusive suites (Fig. 3c): an early suite (431.1 $\pm 1.2 \mathrm{Ma})$ that overlaps temporally with thrust movement, and a late suite $(429.2 \pm 0.5 \mathrm{Ma})$ that post-dates thrust movement (Goodenough et al., 2011). The early suite is largely made up of nepheline syenites with minor mafic-ultramafic rocks (Woolley, 1970) and includes a small calcite carbonatite (sövite) intrusion (Young et al., 1994). The nepheline syenites of Loch Borralan are characterized by a distinctive mineralogical association, including biotite, augite, melanite garnet, nepheline, and pseudomorphs after leucite. The mafic-ultramafic rocks form a steeply-dipping lenticular body at the south-western margin of the intrusion (Notholt et al., 1985). They are dominantly pyroxenites with varying amounts of garnet, amphibole, biotite, apatite, allanite and magnetite plus some pyrite and chalcopyrite; carbonate veining is common (Styles et al., 2004; Notholt et al., 1985). The late suite syenites at Loch Borralan are syenites and quartz syenites (Woolley, 1970). Later nepheline syenite and syenite veins are locally seen to intrude pyroxenite (Parsons and McKirdy, 1983); in our samples this causes pervasive alteration to actinolite, with the formation of perpendicular sodic fenite veins consisting of plagioclase feldspar with accessory barite, strontianite and pyrite and adjacent fine-grained actinolite reaction rims. The pyroxenites show extensive evidence of shearing and brecciation, associated with alteration and the formation of carbon- ate, barite and chlorite. Replacement of syenite by a celestinerich mineral assemblage, also associated with shearing, has been described in one drill core through the ultramafic body (Griffiths, 2011).

Field relationships show that the contacts of the Loch Borralan early suite with the host sedimentary rocks have a sheeted form (Goodenough et al., 2011). This is particularly welldisplayed in outcrops in the marble quarry at Ledbeg, on the western side of the pluton, where sheets of nepheline syenite intrude a carbonate sedimentary sequence. We have studied this locality as part of the HiTech AlkCarb project. Fluids released from the nepheline syenite have caused spectacular metasomatism and remobilization of the host-rock carbonates, with remobilized carbonates locally intruding back into the nepheline syenite (Fig. 4e). Fenitization at the margins of syenite sheets reaches centimetres to tens of centimetres away from the contact. Fenite minerals include phlogopite or amphibole and pyroxene proximal to the syenite, grading into amphibole and phlogopite in a carbonate matrix with distance. Fluids utilising fractures have transported fenitizing fluids considerably further, forming thin veins reaching several metres from the source intrusion. Infrequent REE-micro mineral assemblages occur within the fenitized carbonates, including allanite and burbankite replacing early apatite and phenocrysts within intrusions. Where present, REE minerals are often associated with secondary mineral assemblages, late-stage calcite veins and patches, or substituting into zircon. Locally, there is evidence of brecciation of intrusions and carbonates, which is attributed to the expulsion of fenitizing fluids. Clasts within these breccias are commonly surrounded by reaction rims of biotite altered to chlorite or amphiboles and pyroxenes.

Similar examples of host-rock metasomatism (fenitization) have been recorded elsewhere around the Loch Borralan pluton (Martin et al., 1978; Woolley et al., 1972) and it has been demonstrated that the metasomatizing fluids were enriched in REE (Martin et al., 1978). Our work shows that syenite veins intruding quartzite caused recrystallization of the adjacent quartz and formed thin amphibole-rich metasomatised zones including hornblende, richterite and actinolite with accessory titanite and zircons. In situ mobilization of silica and simultaneous quartz-amphibole crystallization has formed interesting textures consisting of intergrown quartz along amphibole cleavage.

The ca. 425 Ma Loch Loyal Syenite Complex comprises three separate intrusions of syenite and quartz syenite (the Ben Loyal, Beinn Stumanadh and Cnoc nan Cuilean intrusions) that post-date the deformation in their host rocks (Holdsworth et al., 1999). Recent detailed study of the Cnoc nan Cuilean intrusion has shown that it contains mafic syenites rich in clinopyroxene, amphibole, apatite, titanite and allanite (Hughes et al., 2013). Alteration veins within this intrusion (Figs. 4c, 4d) represent the most REE-enriched lithologies known in the NW Scotland complexes (total rare earth oxides up to $2 \mathrm{wt} . \%$ ) and are rich in biotite, magnetite, clinopyroxene, amphibole, K-feldspar, allanite, apatite, and barite with accessory minerals such as ancylite, bastnaesite, strontianite and thorite (Walters et al., 2013). The presence of carbonate minerals in these alteration veins has been interpreted to indicate the possibility that these were pathways exploited by carbonatite or carbonatite-derived fluids in the waning stages of 
magmatic activity (Walters et al., 2013).

The following key features of the ultrapotassic alkaline intrusions of the NW Highlands are particularly relevant for building up the overall model for REE mineral systems in post-collisional alkaline-carbonatite complexes. The mineralogy is distinctive, with mafic to ultramafic rocks characterized by the presence of pyroxene, biotite, magnetite, apatite, sulphides, and REE-bearing minerals such as allanite and titanite (Fig. 5). Unusually, the more leucocratic syenites typically contain less REE-bearing minerals than the mafic lithologies. There is clear evidence for the development of carbonate-rich magmas and fluids in the later stages of magmatism. The evidence for carbonate-sulphate-REE rich alteration at both Loch Borralan and Loch Loyal, indicates that the REE may preferentially partition into late-magmatic fluids. Alteration, or fenite, zones now mark the pathways by which carbonatitic melts or fluids escaped to shallower depths; these fenite zones are themselves typically enriched in REE.

\section{METHODS}

The main aim of this contribution is the collation and review of existing, previously published data. However, we have included new whole-rock geochemical data for six samples from Kizilcaören, six samples from the Eureka carbonatite, 15 samples from the Loch Borralan Complex and one sample from Loch Ailsh in NW Scotland. New whole-rock geochemical data was also collected for eight samples from Mushghai Khudag to add to published data. The methods used for analysis of these new samples are given below.

Whole-rock samples from Loch Ailsh and four samples from Loch Borralan (NWR 001-004) were analyzed by XRF and LA-ICP-MS as per Walters et al. (2013). Whole-rock samples from Loch Borralan (PGD numbers) and Kizilcaören were analyzed for trace elements by ICP-MS following sodium-peroxide fusion and acid-digestion at the British Geological Survey, Keyworth, UK. This method has been adapted from the methodology used for ICP-AES (Walsh et al., 1981).

Whole-rock major element analysis (XRF) for Kizilcaören samples and major (XRF) and trace element (ICP-MS) analysis for samples from Mushghai Khudag was completed commercially at Bureau Veritas, Vancouver, Canada following protocols XF700 for XRF and LF600 for ICP-MS.

Whole-rock samples from Eureka were analyzed commercially by ALS Loughrea, Ireland, by ICP-OES and ICP-MS, following ALS technique code CCP-01. Sample powders were prepared by dissolution of Li metaborate fusions and by 4-acid digestion on unfused powders, the latter technique being used for analysis of $\mathrm{Li}$ and chalcophile elements $(\mathrm{Ag}, \mathrm{As}, \mathrm{Cd}, \mathrm{Co}, \mathrm{Cu}, \mathrm{Mo}$, $\mathrm{Ni}, \mathrm{Pb}, \mathrm{Sc}, \mathrm{Tl}, \mathrm{Zn}$ ). $\mathrm{C}$ and $\mathrm{S}$ were analyzed using a LECO furnace.

\section{RESULTS}

Whole-rock geochemical data for newly analyzed samples from Kizilcaören, Eureka, Northwest Scotland, and Mushghai Khudag are presented in Table 1, and illustrated as part of the wider geochemical dataset in Figs. 6-9. The Kizilcaören dataset includes two samples from alkaline silicate intrusions and four carbonatitic samples, including banded ore material. The two alkaline silicate samples are typical phonolites, with $\mathrm{SiO}_{2}$ con- tents of 54.2 wt. $\%-56.5$ wt. $\%$ and $\mathrm{K}_{2} \mathrm{O}+\mathrm{Na}_{2} \mathrm{O}>13$ wt.\%. Ore and carbonatite samples have $\mathrm{SiO}_{2}<5$ wt. $\%, \mathrm{CaO}>30$ wt. $\%, \mathrm{MgO}<1$ wt.\%, and variable $\mathrm{Fe}_{2} \mathrm{O}_{3}$ (0.46 wt.\%-13.3 wt.\%). Ore samples have high $\mathrm{Ba}(>100000 \mathrm{ppm}), \mathrm{Sr}(>1000 \mathrm{ppm})$ and $\mathrm{SO}_{3}$ contents. Some samples of the Kizilcaören ore veins, which have high Ba contents, are relatively low in La and total REE but these are samples collected at surface; it is likely that these low contents indicate REE mobility in association with weathering.

Six samples of Eureka carbonatite have been analyzed. They have variable $\mathrm{SiO}_{2}$ contents (0.58 wt.\%-12.05 wt.\%). In contrast to Kizilcaören, the Eureka carbonatites have variable contents of $\mathrm{CaO}$ (22.4 wt.\%-41.7 wt.\%), $\mathrm{Fe}_{2} \mathrm{O}_{3}$ (7.0 wt.\%-20.7 wt.\%), and $\mathrm{MgO}$ (1.39 wt.\%-14.9 wt.\%). The trace element budget of Eureka carbonatites is dominated by the REE (total REE 574 ppm-76 614 ppm). Ba contents are low, but this is likely to be a function of the relatively high limit of detection for $\mathrm{BaO}$ in these analyses $(0.01 \mathrm{wt} . \%)$.

The new datasets for samples from NW Scotland only include trace element and REE data, but are presented here as they complement some published datasets that have limited trace element coverage (Table S1). These samples have varying contents of $\mathrm{Ba}$ (up to $7861 \mathrm{ppm}$ ), Sr (up to $37431 \mathrm{ppm}$ ) and total REE (up to $4096 \mathrm{ppm}$ ). The Mushghai Khudag dataset includes one calcite carbonatite and seven alkaline silicate samples. The alkaline silicate rocks vary from phonolitic to alkali rhyolitic, with $\mathrm{SiO}_{2}$ from 52.2 wt.\%-88.5 wt.\%, and $\mathrm{K}_{2} \mathrm{O}$ from $0.03 \mathrm{wt} . \%-10.10 \mathrm{wt} . \%$. The carbonatite sample has relatively high $\mathrm{Ba}$ (14 $356 \mathrm{ppm}), \mathrm{Sr}$ (2 $757 \mathrm{ppm}$ ) and total REE (2 $064 \mathrm{ppm}$ ), whilst the alkaline rocks are highly variable.

\section{DISCUSSION}

\subsection{Geochemical and Isotopic Features}

We have collated published whole-rock geochemical and isotopic data from post-collisional alkaline-carbonatite complexes worldwide, and combined these with our new results, to give as complete an overview as possible of the geochemistry of these complexes. The full set of collated data is available as Table S1. In this section, we discuss the key features that are common to these complexes. We compare the geochemistry of post-collisional alkaline complexes with the classic rift-related alkaline-carbonatite rocks of the East African Rift, in order to highlight differences and similarities between the tectonic settings. The East African Rift geochemical data used for comparison include carbonatite, phonolite, nepheline syenite, syenite and trachyte compositions, and were downloaded from GEOROC (Geochemistry of Rock of the Oceans and Continents) in June 2021.

Most post-collisional alkaline-carbonatite complexes that are of interest for their REE contents comprise carbonatites associated with syenitic, trachytic and phonolitic lithologies (Fig. 6a). Where mafic-ultramafic rocks occur, they typically take the form of amphibolitic or pyroxenitic rocks; gabbroic lithologies are rarely described. The silicate rocks in these complexes may be silica-undersaturated, saturated, or oversaturated. They have compositions that are consistent with the definitions of potassic $\left(\mathrm{K}_{2} \mathrm{O} / \mathrm{Na}_{2} \mathrm{O}\right.$ around or $\left.>1\right)$ to ultrapotassic $\left(\mathrm{K}_{2} \mathrm{O} / \mathrm{Na}_{2} \mathrm{O}>2\right)$ (Peccerillo, 1992; Foley et al., 1987) although it is important to note that most available data (Fig. 6b) are from evolved rocks 
and not parental magma compositions. The carbonatites are typically calciocarbonatites with relatively low $\mathrm{FeO}_{\mathrm{T}}$ and $\mathrm{MgO}$ contents, although more $\mathrm{Mg}$-Fe-rich dolomite carbonatites are present at Eureka and Mountain Pass (Broom-Fendley et al., 2020; Castor, 2008).

The alkaline silicate rocks in these post-collisional settings are typically characterized by high $\mathrm{Ba}, \mathrm{Sr}$ and $\mathrm{Th}$, but low contents of $\mathrm{Nb}, \mathrm{Ta}$ and $\mathrm{Zr}$, relative to rift-related alkaline silicate lithologies (Figs. 6, 7, 8a). Rare earth element patterns for post-collisional alkaline silicate rocks (Fig. 8b) typically show moderate LREE-enrichment, but total REE contents are gener- ally low and similar to those for rift-related alkaline silicate rocks. Notably, Eu anomalies are typically absent from these patterns. This indicates that, in contrast to arc tholeiites, plagioclase fractionation has not exerted a significant control on magmatic compositions.

Post-collisional carbonatites, and the associated baritefluorite-bastnäsite ore veins, are characterized by distinctly high contents of $\mathrm{Ba}$, Th and LREE, but low $\mathrm{Nb}$ and $\mathrm{Ta}$, relative to rift-related carbonatites (Figs. 6, 7, 8c, 8d). Ba and the LREE are also clearly higher in the post-collisional carbonatites than in the associated alkaline silicate rocks (Figs. 7, 9a, 9b).
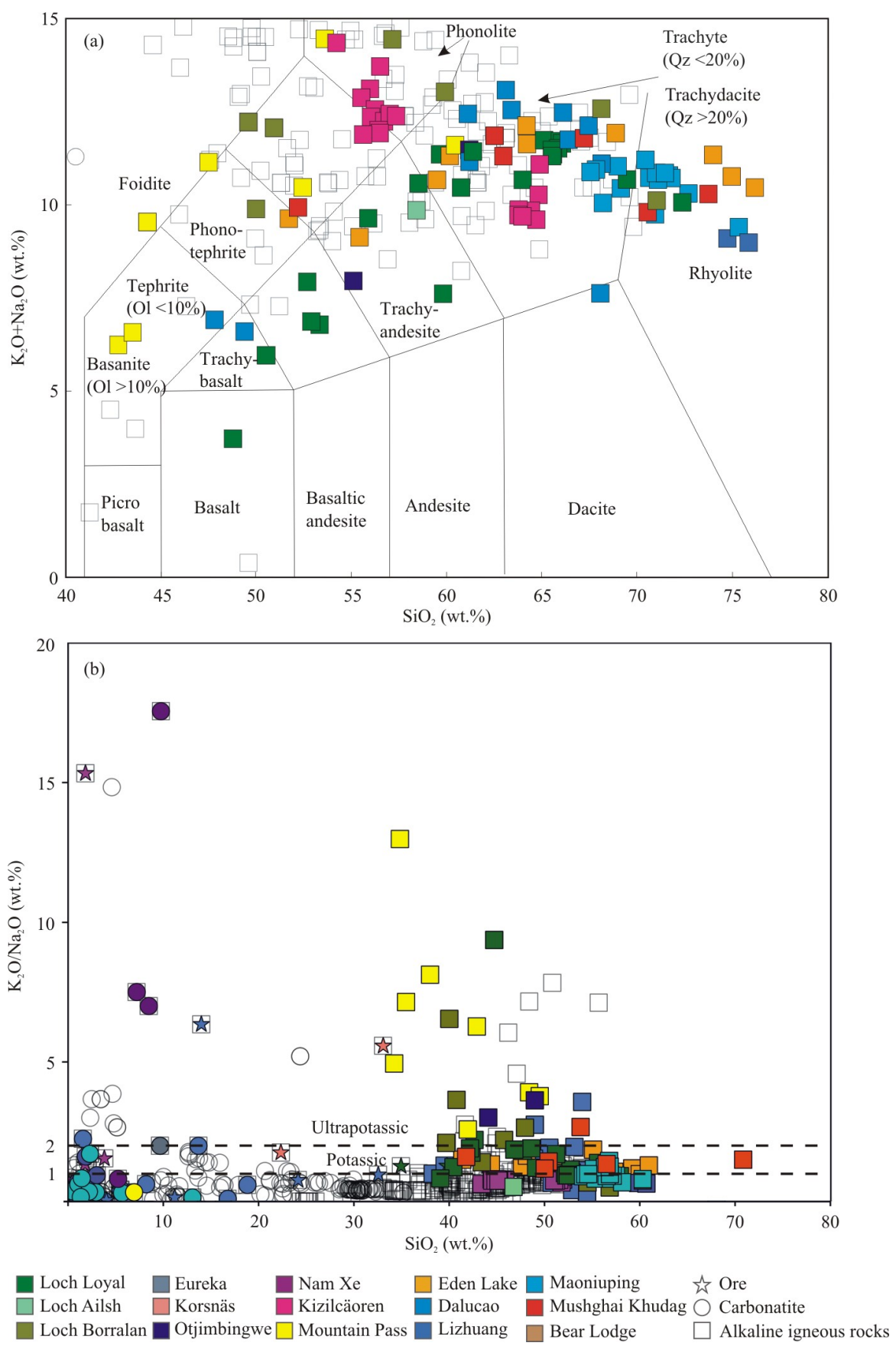

Figure 6. Plots of (a) total alkalis against silica and (b) $\mathrm{K}_{2} \mathrm{O} / \mathrm{Na}_{2} \mathrm{O}$ against $\mathrm{SiO}_{2}$ for alkaline-carbonatite complexes described in the text. Previously unpublished data for Kizilcaören and Loch Borralan from Table 1: all other post-collisional data (filled coloured symbols) from published references cited in the text and shown in Table S1. Note that many carbonatite samples are too low in $\mathrm{SiO}_{2}$ to appear on this plot. Comparative data for the East African Rift (open symbols) downloaded from GEOROC. 
Table 1 Previously unpublished whole-rock geochemical data discussed in this paper

\begin{tabular}{|c|c|c|c|c|c|c|c|c|c|}
\hline Country & Turkey & Turkey & Turkey & Turkey & Turkey & Turkey & Namibia & Namibia & Namibia \\
\hline Complex & Kizilcäoren & Kizilcäoren & Kizilcäoren & Kizilcäoren & Kizilcäoren & Kizilcäoren & Eureka & Eureka & Eureka \\
\hline $\begin{array}{l}\text { Sample } \\
\text { number }\end{array}$ & HTAC 150 & HTAC 178 & HTAC 188 & HTAC 159 & HTAC 160 & HTAC 183 & FWE1 & SoS_60 & SoS_62 \\
\hline Lithology & Ore veins & Ore veins & Ore veins & Alkaline silicate & Alkaline silicate & Carbonatite & Carbonatite & Carbonatite & Carbonatite \\
\hline $\mathrm{SiO}_{2}($ wt.\%) & 2.27 & 2.28 & 4.76 & 56.50 & 54.20 & 0.36 & 1.9 & 8.08 & 12.05 \\
\hline $\mathrm{TiO}_{2}$ & 0.13 & 0.04 & 0.02 & 0.25 & 0.28 & 0.01 & 0.08 & 0.03 & 0.02 \\
\hline $\mathrm{Al}_{2} \mathrm{O}_{3}$ & 0.46 & 0.27 & 2.41 & 19.60 & 19.10 & 0.08 & 0.19 & 0.09 & 0.05 \\
\hline $\mathrm{Fe}_{2} \mathrm{O}_{3}$ & 13.30 & 1.79 & 0.46 & 3.34 & 3.56 & 0.79 & 9.91 & 14.15 & 7 \\
\hline $\mathrm{MnO}$ & 6.84 & 0.36 & 0.01 & 0.19 & 0.18 & 0.27 & 1.05 & 1.77 & 0.92 \\
\hline $\mathrm{MgO}$ & 0.14 & 1.04 & 0.23 & 0.47 & 1.50 & 0.20 & 7.67 & 11.7 & 1.39 \\
\hline $\mathrm{CaO}$ & 30.90 & 39.90 & 37.50 & 1.57 & 1.22 & 52.90 & 25.9 & 25.1 & 41.7 \\
\hline $\mathrm{Na}_{2} \mathrm{O}$ & 0.04 & 0.03 & 0.11 & 7.89 & 8.82 & 0.14 & 0.02 & b.d. & 0.01 \\
\hline $\mathrm{K}_{2} \mathrm{O}$ & 0.02 & 0.46 & 0.17 & 5.83 & 5.53 & 0.08 & b.d. & 0.01 & 0.02 \\
\hline $\mathrm{P}_{2} \mathrm{O}_{5}$ & 0.48 & 0.24 & 0.40 & 0.05 & 0.08 & 1.47 & 3.59 & 1.17 & 0.15 \\
\hline $\mathrm{SO}_{3}$ & 6.38 & 9.57 & 7.53 & 0.11 & 0.08 & 0.49 & - & - & - \\
\hline $\mathrm{F}$ & - & - & - & - & - & - & - & - & - \\
\hline $\mathrm{BaO}$ & - & - & - & - & - & - & 0.01 & 0.01 & 0.04 \\
\hline $\mathrm{SrO}$ & - & - & - & - & - & - & 1.59 & 2.22 & 0.99 \\
\hline $\mathrm{Cr}_{2} \mathrm{O}_{3}$ & $<0.01$ & $<0.01$ & $<0.01$ & $<0.01$ & 0.01 & $<0.01$ & 0.01 & 0.003 & 0.002 \\
\hline $\mathrm{CO}_{2}$ & - & - & - & - & - & - & - & - & - \\
\hline LOI & 5.92 & 14.29 & 5.63 & 4.01 & 5.26 & 40.69 & 33.9 & 34.2 & 35.3 \\
\hline Total & 66.88 & 70.27 & 59.23 & 99.81 & 99.81 & 97.48 & 85.82 & 98.53 & 99.64 \\
\hline $\mathrm{Ba}(\mathrm{ppm})$ & 125400.00 & 163100.00 & 129000.00 & 2800.00 & 2800.00 & 8700.00 & - & - & - \\
\hline $\mathrm{Be}$ & 31.66 & 14.27 & 54.81 & 20.04 & 19.08 & 3.36 & - & - & - \\
\hline $\mathrm{Li}$ & 30.61 & 324.88 & 60.71 & 32.18 & 34.73 & 1.40 & - & - & - \\
\hline $\mathrm{Rb}$ & 1.90 & 33.20 & 5.27 & 153.83 & 106.95 & 1.09 & 6 & b.d. & b.d. \\
\hline $\mathrm{Th}$ & $<4$ & $<4$ & $<4$ & 149.93 & 138.40 & 45.84 & 767 & 208 & 31.5 \\
\hline $\mathrm{Nb}$ & 45.05 & 26.86 & 11.98 & 207.50 & 189.39 & 41.32 & 16 & 11 & 8 \\
\hline $\mathrm{Ta}$ & $<0.08$ & $<0.08$ & $<0.08$ & 5.94 & 5.97 & $<0.08$ & 0.6 & 0.5 & 0.5 \\
\hline $\mathrm{Sr}$ & 1870.00 & 4770.00 & 3650.00 & 1000.00 & 540.00 & 4000.00 & - & - & - \\
\hline $\mathrm{P}$ & 2018.94 & 961.07 & 1750.99 & 113.82 & 266.98 & 6275.77 & - & - & - \\
\hline $\mathrm{Zr}$ & 12.69 & 3.27 & 0.99 & 880.42 & 873.03 & 0.20 & 390 & 30 & 20 \\
\hline Hf & $<0.06$ & $<0.06$ & $<0.06$ & 10.84 & 11.01 & $<0.06$ & 11 & 1 & b.d. \\
\hline $\mathrm{Ti}$ & 726.67 & 183.37 & 32.56 & 1446.41 & 1613.58 & 58.10 & - & - & - \\
\hline $\mathrm{Pb}$ & 180.60 & 238.50 & 203.40 & 61.20 & 57.80 & 227.20 & 81 & 14 & 6 \\
\hline $\mathrm{Sc}$ & - & - & - & - & - & - & 11 & 2 & 1 \\
\hline $\mathrm{Y}$ & 15.69 & 18.13 & 2.02 & 20.42 & 19.91 & 62.07 & 36 & 17 & 16 \\
\hline $\mathrm{La}$ & 186.30 & 159.89 & 92.20 & 99.43 & 79.32 & 323.03 & 24300 & 7630 & 876 \\
\hline $\mathrm{Ce}$ & 862.24 & 140.06 & 102.54 & 142.14 & 133.69 & 179.90 & 38100 & 10950 & 1540 \\
\hline $\operatorname{Pr}$ & 21.39 & 23.09 & 11.30 & 13.84 & 13.86 & 49.26 & 3320 & 912 & 133.5 \\
\hline $\mathrm{Nd}$ & 71.93 & 79.97 & 30.65 & 45.23 & 46.49 & 160.58 & 10150 & 2480 & 413 \\
\hline $\mathrm{Sm}$ & 11.73 & 7.30 & 2.39 & 6.64 & 7.02 & 16.10 & 509 & 149 & 32.6 \\
\hline $\mathrm{Eu}$ & 3.65 & 1.86 & 0.57 & 1.70 & 1.81 & 4.09 & 77.3 & 27.6 & 6.1 \\
\hline $\mathrm{Gd}$ & 11.21 & 6.00 & 1.75 & 4.72 & 4.89 & 12.13 & 119 & 44.4 & 12.8 \\
\hline $\mathrm{Tb}$ & 1.41 & 0.92 & 0.24 & 0.66 & 0.67 & 2.06 & 8.46 & 3.63 & 1.17 \\
\hline Dy & 7.11 & 6.75 & 1.39 & 3.49 & 3.46 & 14.64 & 21 & 7.2 & 4.4 \\
\hline Ho & 1.36 & 1.62 & 0.29 & 0.70 & 0.70 & 3.17 & 2.23 & 0.97 & 0.67 \\
\hline $\mathrm{Er}$ & 3.69 & 4.65 & 0.79 & 2.08 & 1.97 & 8.30 & 4.5 & 2 & 1.5 \\
\hline $\mathrm{Tm}$ & 0.51 & 0.60 & 0.10 & 0.34 & 0.33 & 1.04 & 0.39 & 0.19 & 0.21 \\
\hline $\mathrm{Yb}$ & 2.84 & 3.10 & 0.59 & 2.59 & 2.47 & 5.67 & 2.2 & 1 & 1.2 \\
\hline $\mathrm{Lu}$ & 0.36 & 0.33 & 0.07 & 0.37 & 0.35 & 0.70 & 0.25 & 0.17 & 0.19 \\
\hline Total REE & 1185.72 & 436.14 & 244.87 & 323.95 & 297.01 & 779.97 & 76614.08 & 22207.99 & 3023.15 \\
\hline
\end{tabular}


Table 1 Continued

\begin{tabular}{|c|c|c|c|c|c|c|c|c|c|}
\hline Country & Namibia & Namibia & Namibia & Scotland & Scotland & Scotland & Scotland & Scotland & Scotland \\
\hline \multirow{2}{*}{ Complex } & \multirow{2}{*}{ Eureka } & \multirow{2}{*}{ Eureka } & \multirow{2}{*}{ Eureka } & Loch & Loch & Loch & Loch & Loch & Loch \\
\hline & & & & Ailsh & Borralan & Borralan & Borralan & Borralan & Borralan \\
\hline $\begin{array}{l}\text { Sample } \\
\text { number }\end{array}$ & Eu-6 & $\mathrm{Eu}-9$ & $\mathrm{Eu}-10$ & NWR-004 & NWR-002 & NWR-003 & NWR-001 & NWR-001A & PGD 7281 \\
\hline Lithology & $\begin{array}{c}\text { Carbo- } \\
\text { natite }\end{array}$ & $\begin{array}{c}\text { Carbo- } \\
\text { natite }\end{array}$ & $\begin{array}{c}\text { Carbo- } \\
\text { natite }\end{array}$ & $\begin{array}{l}\text { Alkaline } \\
\text { silicate }\end{array}$ & $\begin{array}{c}\text { Alkaline } \\
\text { silicate }\end{array}$ & $\begin{array}{l}\text { Alkaline } \\
\text { silicate }\end{array}$ & $\begin{array}{l}\text { Alkaline } \\
\text { silicate }\end{array}$ & $\begin{array}{l}\text { Alkaline } \\
\text { silicate }\end{array}$ & $\begin{array}{l}\text { Alkaline } \\
\text { silicate }\end{array}$ \\
\hline $\mathrm{SiO}_{2}($ wt. $\%)$ & 1.47 & 1.26 & 0.58 & 58.41 & 50.94 & 57.16 & - & - & - \\
\hline $\mathrm{TiO}_{2}$ & & 0.01 & 0.01 & 0.46 & 0.98 & 0.18 & - & - & - \\
\hline $\mathrm{Al}_{2} \mathrm{O}_{3}$ & 0.11 & 0.25 & 0.1 & 15.36 & 18.93 & 20.55 & - & - & - \\
\hline $\mathrm{Fe}_{2} \mathrm{O}_{3}$ & 20.7 & 11 & 13.8 & 5 & 5.56 & 4.24 & - & - & - \\
\hline $\mathrm{MnO}$ & 1.34 & 1.37 & 1.34 & 0.11 & 0.13 & 0.09 & - & - & - \\
\hline $\mathrm{MgO}$ & 14.75 & 12.7 & 14.9 & 4.65 & 0.76 & 0.34 & - & - & - \\
\hline $\mathrm{CaO}$ & 22.4 & 28.8 & 23.8 & 4.17 & 6.44 & 0.51 & - & - & - \\
\hline $\mathrm{Na}_{2} \mathrm{O}$ & 0.02 & b.d. & 0.02 & 6.46 & 2.6 & 4.51 & - & - & - \\
\hline $\mathrm{K}_{2} \mathrm{O}$ & b.d. & b.d. & 0.01 & 3.4 & 9.46 & 9.94 & - & - & - \\
\hline $\mathrm{P}_{2} \mathrm{O}_{5}$ & b.d. & 0.5 & 3.49 & 0.22 & 0.12 & $<0.01$ & - & - & - \\
\hline $\mathrm{SO}_{3}$ & - & - & - & - & - & - & - & - & - \\
\hline $\mathrm{F}$ & - & - & - & - & - & - & - & - & - \\
\hline $\mathrm{BaO}$ & 0.01 & b.d. & 0.01 & - & - & - & - & - & - \\
\hline $\mathrm{SrO}$ & 1.48 & 3.25 & 2.77 & - & - & - & - & - & - \\
\hline $\mathrm{Cr}_{2} \mathrm{O}_{3}$ & b.d. & 0.002 & 0.004 & - & - & - & - & - & - \\
\hline $\mathrm{CO}_{2}$ & - & - & - & - & - & - & - & - & - \\
\hline LOI & 36 & 39.3 & 34.8 & 1.38 & 2.68 & 1.81 & - & - & - \\
\hline Total & 98.28 & 98.44 & 95.63 & 100.16 & 100.28 & 99.7 & - & - & - \\
\hline $\mathrm{Ba}(\mathrm{ppm})$ & - & - & - & 2171.05 & 7861.68 & 211.40 & 109.49 & 151.99 & 499.97 \\
\hline $\mathrm{Be}$ & - & - & - & - & - & - & - & - & 13.36 \\
\hline $\mathrm{Li}$ & - & - & - & - & - & - & - & - & 16.54 \\
\hline $\mathrm{Rb}$ & 2 & b.d. & b.d. & 69.08 & 295.52 & 283.21 & 2.44 & 5.30 & 49.41 \\
\hline Th & 0.8 & 82.5 & 648 & 13.97 & 8.76 & 44.24 & b.d. & b.d. & 81.24 \\
\hline $\mathrm{Nb}$ & 1 & 6 & 7 & 9.90 & 7.33 & 28.42 & 0.50 & 0.71 & 40.34 \\
\hline $\mathrm{Ta}$ & b.d. & 0.5 & 0.6 & 0.08 & 0.32 & 0.74 & 0.05 & 0.07 & 1.81 \\
\hline $\mathrm{Sr}$ & - & - & - & 1685.74 & 3158.86 & 938.24 & 13268.24 & 12943.24 & 1027.51 \\
\hline $\mathrm{P}$ & - & - & - & 1116.47 & 589.47 & b.d. & 1830.84 & 2159.59 & 867.02 \\
\hline $\mathrm{Zr}$ & 100 & 10 & 10 & 171.15 & 437.21 & 1591.21 & b.d. & 8.56 & 906.89 \\
\hline Hf & 2 & b.d. & b.d. & 4.28 & 11.51 & 30.21 & b.d. & 0.22 & 24.50 \\
\hline $\mathrm{Ti}$ & - & - & - & 3444.95 & 6013.70 & 1183.39 & 388.20 & 248.45 & - \\
\hline $\mathrm{Pb}$ & 6 & 6 & 38 & 34.1 & b.d. & b.d. & b.d. & b.d. & 21.5 \\
\hline $\mathrm{Sc}$ & 1 & 2 & b.d. & - & - & - & - & - & - \\
\hline $\mathrm{Y}$ & 7 & 18 & 33 & 15.37 & 48.11 & 3.56 & 2.95 & 4.61 & 110.75 \\
\hline $\mathrm{La}$ & 134 & 3180 & 21300 & 47.21 & 44.13 & 20.62 & 132.51 & 161.07 & 340.27 \\
\hline $\mathrm{Ce}$ & 283 & 4910 & 33100 & 87.9 & 145.72 & 41.07 & 73.97 & 110.4 & 656.91 \\
\hline $\operatorname{Pr}$ & 30 & 424 & 2960 & 10.22 & 24.52 & 3.38 & 12.86 & 16.29 & 67.45 \\
\hline $\mathrm{Nd}$ & 105.5 & 1260 & 8940 & 37.55 & 121.84 & 9.65 & 35.7 & 45.55 & 254.41 \\
\hline $\mathrm{Sm}$ & 10.1 & 82.2 & 512 & 6.44 & 24.54 & 1.12 & 3.36 & 4.64 & 52.77 \\
\hline $\mathrm{Eu}$ & 2.2 & 20.5 & 84.9 & 1.94 & 6.79 & 0.3 & 0.87 & 1.14 & 15.27 \\
\hline $\mathrm{Gd}$ & 5 & 28 & 122.5 & 4.8 & 16.35 & 0.81 & 2.02 & 2.79 & 42.98 \\
\hline $\mathrm{Tb}$ & 0.49 & 2.1 & 8.17 & 0.6 & 2.11 & 0.11 & 0.22 & 0.3 & 5.8 \\
\hline Dy & 1.8 & 6.2 & 18.9 & 3.18 & 10.07 & 0.59 & 1.05 & 1.57 & 27.23 \\
\hline Ho & 0.28 & 0.89 & 2.05 & 0.56 & 1.55 & 0.1 & 0.18 & 0.24 & 4.01 \\
\hline Er & 0.8 & 1.6 & 4 & 1.56 & 3.83 & 0.25 & 0.42 & 0.58 & 9.6 \\
\hline $\mathrm{Tm}$ & 0.11 & 0.23 & 0.29 & 0.22 & 0.52 & 0.04 & 0.05 & 0.07 & 1.15 \\
\hline $\mathrm{Yb}$ & 0.7 & 1.4 & 1.9 & 1.41 & 3.15 & 0.29 & 0.28 & 0.46 & 6.79 \\
\hline $\mathrm{Lu}$ & 0.08 & 0.19 & 0.16 & 0.23 & 0.44 & 0.05 & 0.04 & 0.06 & 0.92 \\
\hline Total REE & 573.98 & 9917.12 & 67054.71 & 203.84 & 405.56 & 78.37 & 263.49 & 345.1 & 1485.57 \\
\hline
\end{tabular}


Table 1 Continued

\begin{tabular}{|c|c|c|c|c|c|c|c|c|c|}
\hline Country & Scotland & Scotland & Scotland & Scotland & Scotland & Scotland & Scotland & Scotland & Scotland \\
\hline \multirow{2}{*}{ Complex } & Loch & Loch & Loch & Loch & Loch & Loch & Loch & Loch & Loch \\
\hline & Borralan & Borralan & Borralan & Borralan & Borralan & Borralan & Borralan & Borralan & Borralan \\
\hline $\begin{array}{l}\text { Sample } \\
\text { number }\end{array}$ & PGD 7257 & PGD 7261 & PGD 7277 & PGD 7347 & PGD 7368 & PGD 7382 & PGD 7431 & PGD 7467 & PGD 7516 \\
\hline Lithology & $\begin{array}{l}\text { Alkaline } \\
\text { silicate }\end{array}$ & $\begin{array}{l}\text { Alkaline } \\
\text { silicate }\end{array}$ & $\begin{array}{l}\text { Alkaline } \\
\text { silicate }\end{array}$ & $\begin{array}{l}\text { Alkaline } \\
\text { silicate }\end{array}$ & $\begin{array}{l}\text { Alkaline } \\
\text { silicate }\end{array}$ & $\begin{array}{c}\text { Alkaline } \\
\text { silicate }\end{array}$ & $\begin{array}{l}\text { Alkaline } \\
\text { silicate }\end{array}$ & $\begin{array}{l}\text { Alkaline } \\
\text { silicate }\end{array}$ & $\begin{array}{c}\text { Alkaline } \\
\text { silicate }\end{array}$ \\
\hline $\mathrm{SiO}_{2}$ (wt.\%) & - & - & - & - & - & - & - & - & - \\
\hline $\mathrm{TiO}_{2}$ & - & - & - & - & - & - & - & - & - \\
\hline $\mathrm{Al}_{2} \mathrm{O}_{3}$ & - & - & - & - & - & - & - & - & - \\
\hline $\mathrm{Fe}_{2} \mathrm{O}_{3}$ & - & - & - & - & - & - & - & - & - \\
\hline $\mathrm{MnO}$ & - & - & - & - & - & - & - & - & - \\
\hline $\mathrm{MgO}$ & - & - & - & - & - & - & - & - & - \\
\hline $\mathrm{CaO}$ & - & - & - & - & - & - & - & - & - \\
\hline $\mathrm{Na}_{2} \mathrm{O}$ & - & - & - & - & - & - & - & - & - \\
\hline $\mathrm{K}_{2} \mathrm{O}$ & - & - & - & - & - & - & - & - & - \\
\hline $\mathrm{P}_{2} \mathrm{O}_{5}$ & - & - & - & - & - & - & - & - & - \\
\hline $\mathrm{SO}_{3}$ & - & - & - & - & - & - & - & - & - \\
\hline $\mathrm{F}$ & - & - & - & - & - & - & - & - & - \\
\hline $\mathrm{BaO}$ & - & - & - & - & - & - & - & - & - \\
\hline $\mathrm{SrO}$ & - & - & - & - & - & - & - & - & - \\
\hline $\mathrm{Cr}_{2} \mathrm{O}_{3}$ & - & - & - & - & - & - & - & - & - \\
\hline $\mathrm{CO}_{2}$ & - & - & - & - & - & - & - & - & - \\
\hline LOI & - & - & - & - & - & - & - & - & - \\
\hline Total & - & - & - & - & - & - & - & - & - \\
\hline $\mathrm{Ba}(\mathrm{ppm})$ & 589.44 & 552.72 & 222.38 & 430.34 & 490.64 & 2778.27 & 813.04 & 432.57 & 2931.25 \\
\hline $\mathrm{Be}$ & 7.72 & 3.51 & 9.10 & 8.08 & 1.17 & 1.29 & 5.35 & 2.30 & 5.55 \\
\hline $\mathrm{Li}$ & 38.68 & 25.93 & 9.21 & 132.04 & 8.24 & 33.81 & 24.65 & 12.35 & 30.79 \\
\hline $\mathrm{Rb}$ & 80.99 & 58.23 & 29.89 & 82.66 & 29.77 & 30.20 & 88.44 & 59.82 & 44.88 \\
\hline $\mathrm{Th}$ & 36.34 & 40.41 & 279.26 & 53.00 & 3.62 & 11.21 & 29.10 & 30.92 & 102.59 \\
\hline $\mathrm{Nb}$ & 91.90 & 29.65 & 52.61 & 27.09 & 12.42 & 4.81 & 7.84 & 7.83 & 13.89 \\
\hline $\mathrm{Ta}$ & 2.03 & 1.93 & 1.46 & 0.56 & 0.69 & 0.19 & 0.28 & 0.59 & 0.57 \\
\hline $\mathrm{Sr}$ & 2349.78 & 1361.68 & 1165.84 & 2411.02 & 423.11 & 37431.88 & 1600.25 & 1083.29 & 4138.22 \\
\hline $\mathrm{P}$ & 3205.94 & 4322.95 & 1852.52 & 20287.93 & 660.02 & 3080.15 & 11197.58 & 4368.11 & 19894.14 \\
\hline $\mathrm{Zr}$ & 2205.86 & 1943.99 & 2472.52 & 86.61 & 80.54 & 34.28 & 401.94 & 928.82 & 216.50 \\
\hline $\mathrm{Hf}$ & 68.50 & 50.40 & 53.10 & 2.40 & 2.40 & 0.90 & 13.00 & 19.30 & 5.00 \\
\hline $\mathrm{Ti}$ & - & - & - & - & - & - & - & - & - \\
\hline $\mathrm{Pb}$ & 65.20 & 23.60 & 398.00 & 47.30 & 11.20 & 713.50 & 16.50 & 12.00 & 14.30 \\
\hline $\mathrm{Sc}$ & - & - & - & - & - & - & - & - & - \\
\hline $\mathrm{Y}$ & 325.29 & 266.74 & 170.86 & 207.05 & 17.40 & 52.70 & 88.20 & 72.56 & 60.72 \\
\hline $\mathrm{La}$ & 243.77 & 213.89 & 1208.65 & 294.51 & 19.78 & 413.22 & 221.65 & 173.06 & 359.7 \\
\hline $\mathrm{Ce}$ & 654.29 & 638.82 & 1830.78 & 754.86 & 42.86 & 819.47 & 476.9 & 471.02 & 755.06 \\
\hline $\operatorname{Pr}$ & 87.69 & 100.52 & 169.32 & 104.36 & 4.48 & 85.37 & 61.79 & 73.98 & 84.17 \\
\hline $\mathrm{Nd}$ & 426.73 & 542.79 & 589.17 & 477.70 & 18.84 & 299.32 & 274.77 & 359.62 & 311.53 \\
\hline $\mathrm{Sm}$ & 132.09 & 135.63 & 103.61 & 97.76 & 3.75 & 37.85 & 60.01 & 60.32 & 45.53 \\
\hline $\mathrm{Eu}$ & 40.30 & 38.02 & 26.93 & 21.43 & 1.22 & 10.34 & 16.67 & 14.02 & 10.44 \\
\hline $\mathrm{Gd}$ & 120.70 & 102.37 & 76.22 & 75.62 & 3.81 & 22.27 & 49.11 & 32.73 & 29.31 \\
\hline $\mathrm{Tb}$ & 16.41 & 12.16 & 9.50 & 8.76 & 0.60 & 2.37 & 5.71 & 3.65 & 3.24 \\
\hline Dy & 80.37 & 58.70 & 44.47 & 42.10 & 3.53 & 10.58 & 25.53 & 16.22 & 14.52 \\
\hline Ho & 12.38 & 8.85 & 6.73 & 7.33 & 0.69 & 1.80 & 3.57 & 2.43 & 2.3 \\
\hline $\mathrm{Er}$ & 29.26 & 20.68 & 15.94 & 19.05 & 1.96 & 4.56 & 7.51 & 5.69 & 5.26 \\
\hline $\mathrm{Tm}$ & 3.50 & 2.66 & 1.95 & 2.35 & 0.27 & 0.61 & 0.84 & 0.74 & 0.59 \\
\hline $\mathrm{Yb}$ & 19.85 & 15.94 & 11.59 & 13.23 & 1.69 & 3.93 & 4.48 & 4.24 & 3.11 \\
\hline $\mathrm{Lu}$ & 2.66 & 2.25 & 1.57 & 1.67 & 0.24 & 0.62 & 0.64 & 0.6 & 0.38 \\
\hline Total REE & 1870.00 & 1893.29 & 4096.42 & 1920.75 & 103.72 & 1712.32 & 1209.18 & 1218.33 & 1625.15 \\
\hline
\end{tabular}


Table 1 Continued

\begin{tabular}{|c|c|c|c|c|c|c|c|c|c|}
\hline Country & Scotland & Mongolia & Mongolia & Mongolia & Mongolia & Mongolia & Mongolia & Mongolia & Mongolia \\
\hline Complex & $\begin{array}{c}\text { Loch } \\
\text { Borralan } \\
\end{array}$ & $\begin{array}{c}\text { Mushghai } \\
\text { Khudag }\end{array}$ & $\begin{array}{c}\text { Mushghai } \\
\text { Khudag }\end{array}$ & $\begin{array}{l}\text { Mushghai } \\
\text { Khudag }\end{array}$ & $\begin{array}{l}\text { Mushghai } \\
\text { Khudag }\end{array}$ & $\begin{array}{c}\text { Mushghai } \\
\text { Khudag }\end{array}$ & $\begin{array}{c}\text { Mushghai } \\
\text { Khudag }\end{array}$ & $\begin{array}{l}\text { Mushghai } \\
\text { Khudag }\end{array}$ & $\begin{array}{c}\text { Mushghai } \\
\text { Khudag }\end{array}$ \\
\hline $\begin{array}{l}\text { Sample } \\
\text { number }\end{array}$ & $\begin{array}{l}\text { PGD } \\
7544 \\
\end{array}$ & $\begin{array}{c}\text { HTAC_221 } \\
5 \\
\end{array}$ & HTAC_2201 & $\begin{array}{c}\mathrm{HTAC}_{\overline{\mathrm{A}}} 2203 \\
\end{array}$ & HTAC_2207 & HTAC_2208 & HTAC_2211 & HTAC_2212 & HTAC_2214 \\
\hline Lithology & $\begin{array}{c}\text { Alkaline } \\
\text { silicate }\end{array}$ & Carbonatite & $\begin{array}{c}\text { Alkaline } \\
\text { silicate }\end{array}$ & $\begin{array}{c}\text { Alkaline } \\
\text { silicate }\end{array}$ & $\begin{array}{c}\text { Alkaline } \\
\text { silicate }\end{array}$ & $\begin{array}{c}\text { Alkaline } \\
\text { silicate }\end{array}$ & $\begin{array}{c}\text { Alkaline } \\
\text { silicate }\end{array}$ & $\begin{array}{c}\text { Alkaline } \\
\text { silicate }\end{array}$ & $\begin{array}{c}\text { Alkaline } \\
\text { silicate }\end{array}$ \\
\hline $\mathrm{SiO}_{2}$ (wt.\%) & - & 1.87 & 52.2 & 88.50 & 63.00 & 73.70 & 62.50 & 70.60 & 67.20 \\
\hline $\mathrm{TiO}_{2}$ & - & 0.01 & 0.97 & 0.01 & 0.67 & 0.09 & 0.54 & 0.49 & 0.40 \\
\hline $\mathrm{Al}_{2} \mathrm{O}_{3}$ & - & 0.14 & 17.1 & 0.05 & 15.60 & 11.80 & 17.50 & 14.00 & 14.80 \\
\hline $\mathrm{Fe}_{2} \mathrm{O}_{3}$ & - & 1.38 & 6.39 & 0.37 & 2.99 & 0.59 & 3.54 & 1.85 & 2.50 \\
\hline $\mathrm{MnO}$ & - & 0.44 & 0.1 & 0.07 & 0.12 & 0.01 & 0.04 & 0.03 & 0.06 \\
\hline $\mathrm{MgO}$ & - & 0.15 & 3.04 & 0.57 & 1.39 & 0.08 & 0.40 & 0.37 & 0.12 \\
\hline $\mathrm{CaO}$ & - & 52.1 & 5.47 & 4.66 & 2.60 & 1.52 & 2.07 & 1.10 & 1.06 \\
\hline $\mathrm{Na}_{2} \mathrm{O}$ & - & $<0.01$ & 3.81 & 0.02 & 4.64 & 0.18 & 5.42 & 4.19 & 3.21 \\
\hline $\mathrm{K}_{2} \mathrm{O}$ & - & 0.06 & 6.11 & 0.03 & 6.66 & 10.10 & 6.42 & 5.62 & 8.57 \\
\hline $\mathrm{P}_{2} \mathrm{O}_{5}$ & - & 0.48 & 1.19 & 0.76 & 0.31 & 0.03 & 0.34 & 0.16 & 0.09 \\
\hline $\mathrm{SO}_{3}$ & - & 0.99 & 0.16 & 0.69 & 0.35 & 0.29 & 0.02 & 0.07 & 0.15 \\
\hline F & - & - & - & - & - & - & - & - & - \\
\hline $\mathrm{BaO}$ & - & - & - & - & - & - & - & - & - \\
\hline $\mathrm{SrO}$ & - & - & - & - & - & - & - & - & - \\
\hline $\mathrm{Cr}_{2} \mathrm{O}_{3}$ & - & $<0.01$ & $<0.01$ & 0.01 & $<0.01$ & $<0.01$ & $<0.01$ & $<0.01$ & $<0.01$ \\
\hline $\mathrm{CO}_{2}$ & - & - & - & - & - & - & - & - & - \\
\hline LOI & - & 39.68 & 1.37 & 2.88 & 0.60 & 1.09 & 1.02 & 0.96 & 1.33 \\
\hline Total & - & 97.299 & 97.907 & 98.61 & 98.93 & 99.48 & 99.81 & 99.44 & 99.49 \\
\hline $\mathrm{Ba}(\mathrm{ppm})$ & 420.06 & 14356.00 & 7106.00 & 8579.00 & 2675.00 & 192.00 & 1518.00 & 735.00 & 1353.00 \\
\hline $\mathrm{Be}$ & 2.32 & 3.00 & 4.00 & & 6.00 & 4.00 & 4.00 & 3.00 & 6.00 \\
\hline $\mathrm{Li}$ & 4.68 & 0.29 & 1.15 & 0.08 & 0.51 & 0.03 & 0.23 & 0.13 & 0.03 \\
\hline $\mathrm{Rb}$ & 232.08 & 1.20 & 77.20 & 0.40 & 169.80 & 521.50 & 133.20 & 130.90 & 175.50 \\
\hline Th & 24.69 & 0.80 & 12.10 & 0.50 & 69.10 & 106.30 & 26.90 & 27.20 & 47.30 \\
\hline $\mathrm{Nb}$ & 5.52 & 1.50 & 32.70 & 4.90 & 42.10 & 44.60 & 19.70 & 25.40 & 36.20 \\
\hline $\mathrm{Ta}$ & 0.47 & 0.20 & 0.60 & 0.10 & 2.60 & 2.00 & 1.20 & 1.40 & 2.40 \\
\hline $\mathrm{Sr}$ & 1491.14 & 2756.70 & 10478.90 & 730.80 & 4841.20 & 238.70 & 2131.20 & 1073.30 & 201.30 \\
\hline $\mathrm{P}$ & 6482.40 & - & - & - & - & - & - & - & - \\
\hline $\mathrm{Zr}$ & 564.00 & 94.50 & 241.90 & 126.60 & 699.40 & 335.60 & 495.90 & 554.50 & 610.70 \\
\hline $\mathrm{Hf}$ & 11.80 & 0.50 & 4.50 & 0.90 & 17.70 & 14.20 & 10.00 & 11.80 & 14.80 \\
\hline $\mathrm{Ti}$ & - & - & - & - & - & - & - & - & - \\
\hline $\mathrm{Pb}$ & 41.50 & 40.00 & 20.80 & 150.30 & 38.20 & 9.80 & 15.60 & 34.60 & 56.50 \\
\hline $\mathrm{Sc}$ & - & - & - & - & - & - & - & - & - \\
\hline $\mathrm{Y}$ & 58.61 & 33.60 & 24.20 & 10.20 & 20.90 & 18.30 & 27.80 & 26.30 & 35.20 \\
\hline $\mathrm{La}$ & 220.08 & 733 & 143.4 & 408.30 & 90.90 & 46.40 & 152.20 & 145.50 & 175.10 \\
\hline $\mathrm{Ce}$ & 572.77 & 963.8 & 289.1 & 488.30 & 180.20 & 81.00 & 320.00 & 278.60 & 321.00 \\
\hline Pr & 77.62 & 83.13 & 34.08 & 38.86 & 20.03 & 6.77 & 35.77 & 31.15 & 32.81 \\
\hline $\mathrm{Nd}$ & 326.64 & 231.5 & 133.1 & 102.20 & 71.80 & 17.30 & 127.40 & 103.30 & 101.90 \\
\hline $\mathrm{Sm}$ & 43.59 & 21.29 & 19.11 & 8.51 & 10.72 & 2.22 & 17.74 & 14.21 & 14.18 \\
\hline $\mathrm{Eu}$ & 10.04 & 6.95 & 5.4 & 4.06 & 2.70 & 0.46 & 4.52 & 2.65 & 2.43 \\
\hline $\mathrm{Gd}$ & 24.84 & 12.08 & 11.99 & 4.37 & 6.54 & 2.07 & 10.69 & 8.65 & 8.58 \\
\hline $\mathrm{Tb}$ & 2.94 & 1.22 & 1.25 & 0.40 & 0.78 & 0.32 & 1.25 & 1.04 & 1.18 \\
\hline Dy & 13.68 & 5.48 & 5.44 & 1.68 & 4.02 & 2.01 & 5.77 & 5.21 & 6.56 \\
\hline Ho & 2.05 & 0.85 & 0.77 & 0.22 & 0.67 & 0.45 & 0.90 & 0.84 & 1.18 \\
\hline Er & 4.67 & 2.22 & 1.93 & 0.61 & 1.97 & 1.64 & 2.38 & 2.69 & 3.73 \\
\hline $\mathrm{Tm}$ & 0.57 & 0.28 & 0.27 & 0.07 & 0.29 & 0.26 & 0.35 & 0.36 & 0.53 \\
\hline $\mathrm{Yb}$ & 3.33 & 1.74 & 1.64 & 0.53 & 2.12 & 1.90 & 2.25 & 2.16 & 3.70 \\
\hline $\mathrm{Lu}$ & 0.45 & 0.25 & 0.24 & 0.06 & 0.34 & 0.30 & 0.32 & 0.37 & 0.58 \\
\hline Total REE & 1303.28 & 2063.54 & 647.72 & 1058.11 & 393.08 & 163.10 & 681.54 & 596.73 & 673.46 \\
\hline
\end{tabular}

“-” indicates "not analyzed" and "b.d." is "below detection limit". 

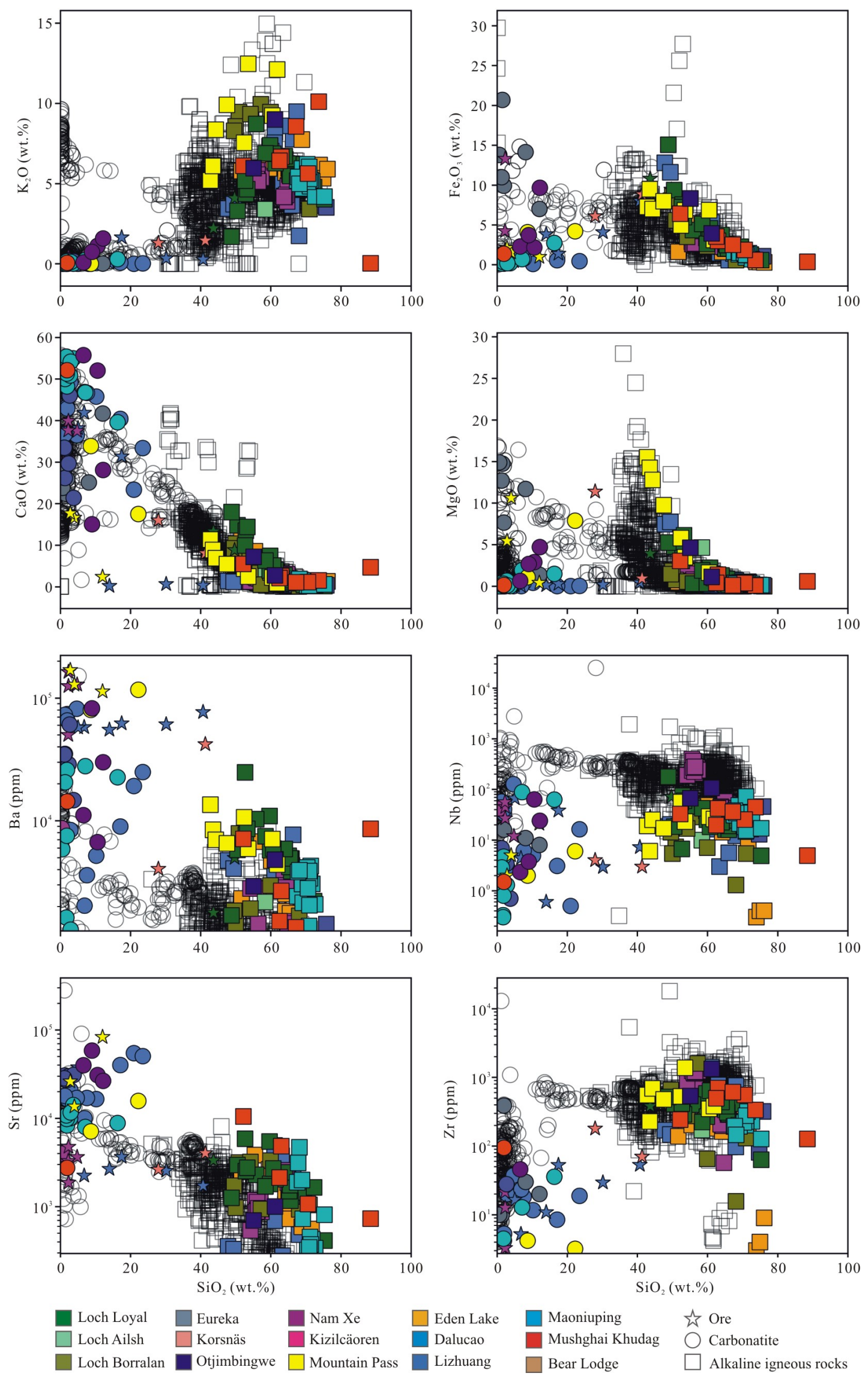

Figure 7. Plots of selected major oxides and trace elements against $\mathrm{SiO}_{2}$ for alkaline-carbonatite complexes described in the text. Previously unpublished data for Kizilcaören, Eureka and Loch Borralan from Table 1: all other post-collisional data (filled, coloured symbols) from published references cited in the text and shown in Table S1. Comparative data for the East African Rift (open symbols) downloaded from GEOROC. 

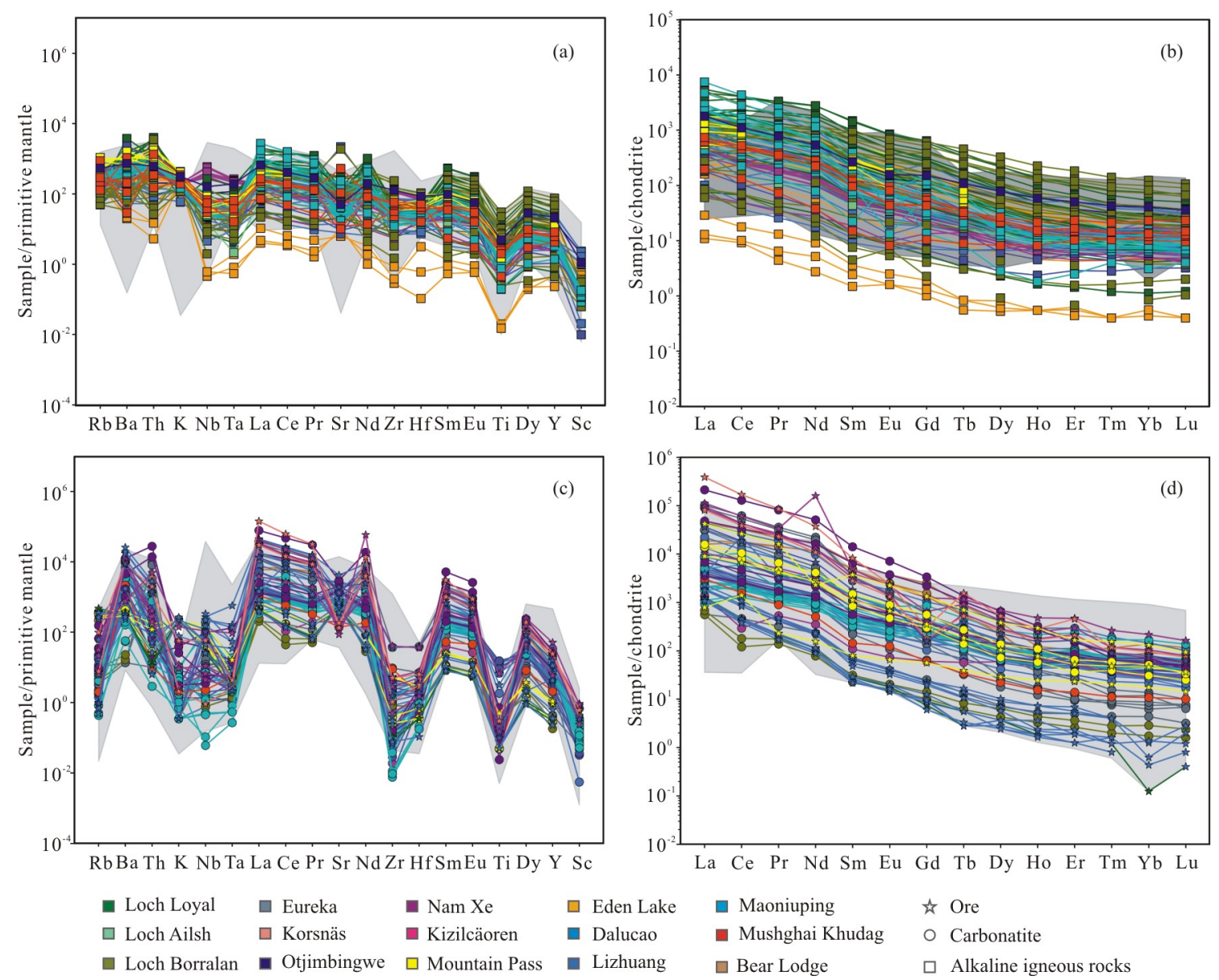

Figure 8. Trace and rare earth element plots for collated samples in this paper. Previously unpublished data for Kizilcaören, Eureka and Loch Borralan from Table 1: all other post-collisional data (filled, coloured symbols) from published references cited in the text and shown in Table S1. (a) Primitive mantlenormalized trace element plots for alkaline silicate rocks; (b) chondrite-normalized rare earth element plots for alkaline silicate rocks; (c) primitive mantlenormalized trace element plots for carbonatites; (d) chondrite-normalized rare earth element plots for carbonatites. Normalising factors from McDonough and Sun (1995). Pale grey field indicates the extent of the East African Rift dataset.

Liu and Hou (2017) suggested that $\mathrm{Sr} / \mathrm{Ba}$ typically correlates negatively with REE content, with $\mathrm{Sr} / \mathrm{Ba}$ commonly higher in the alkaline silicate lithologies than in the corresponding carbonatites (Fig. 9b). There is some evidence of this in our collated dataset, but the correlation is not a strong one. Most of the post-collisional carbonatites described here fall within the 'mineralized' field of Liu and Hou (2017), with the exception of the Loch Borralan carbonatite, which has a relatively high $\mathrm{Sr} / \mathrm{Ba}$ ratio and is unusually low in REE. In contrast, rift-related carbonatites from the East African Rift fall in the 'barren' field on this plot (Fig. 9b). A plot of Ba/Nb vs. La/Nb (Fig. 9a) effectively discriminates post-collisional carbonatites and associated mineralization from their associated alkaline silicate rocks and also from rift-related carbonatites of the East African Rift.

A review of experimental data available at the time led Chakhmouradian et al. (2008) to suggest that $\mathrm{Ba} / \mathrm{Mn}, \mathrm{Ba} / \mathrm{La}$ and $\mathrm{Nb} / \mathrm{Th}$ would be expected to be higher in immiscible carbonatite melts than in the associated alkaline silicate rocks, but they also noted that this was not the case for their samples from Eden Lake. Our combined dataset shows that post-collisional alkaline silicate rocks have quite tightly clustered $\mathrm{Ba} / \mathrm{Mn}$ and $\mathrm{Nb} / \mathrm{Th}$ ratios, but that the carbonatites are much more variable (Fig. 9c). Eureka, which is not associated with alkaline silicate rocks, has lower
$\mathrm{Ba} / \mathrm{Mn}$ than other carbonatites; Maoniuping carbonatites also show low $\mathrm{Ba} / \mathrm{Mn}$. Most post-collisional carbonatites have lower $\mathrm{Nb} / \mathrm{Th}$ than the associated alkaline rocks, the exception being some carbonatites from Dalucao. The East African Rift dataset has higher $\mathrm{Ba} / \mathrm{Mn}$ in the carbonatites than the alkaline silicate rocks, whilst $\mathrm{Nb} / \mathrm{Th}$ is relatively consistent. The post-collisional carbonatites typically have noticeably lower $\mathrm{Nb} / \mathrm{Th}$ ratios than those of the East African Rift, and this ratio represents the best discriminant between rift-related and post-collisional settings.

It has been proposed that rocks formed by carbothermal fluids should have $\mathrm{Rb} / \mathrm{Sr}, \mathrm{Y} / \mathrm{Ce}$ and $\mathrm{Nb} / \mathrm{Th}$ ratios higher than those in the residual silicate magma at comparable $\mathrm{Y} / \mathrm{Zr}$ values (Chakhmouradian et al., 2008). In both our post-collisional dataset and the East African Rift dataset, the alkaline silicate rocks have higher $\mathrm{Rb} / \mathrm{Sr}$ and lower $\mathrm{Y} / \mathrm{Zr}$ than the carbonatites (Fig. 9d). However it is notable that the barite-fluorite-bastnäsite ore veins at Kizilcaören, Lizhuang and Dalucao typically have higher $\mathrm{Rb} / \mathrm{Sr}$ than the carbonatites at the same $\mathrm{Y} / \mathrm{Zr}$ value. $\mathrm{Y} / \mathrm{Zr}$ is notably higher in post-collisional carbonatites than those of the East African Rift.

The alkaline-carbonatite complexes of the MianningDechang belt have been very well-characterized in terms of radiogenic isotope composition, as summarized by Liu and Hou 

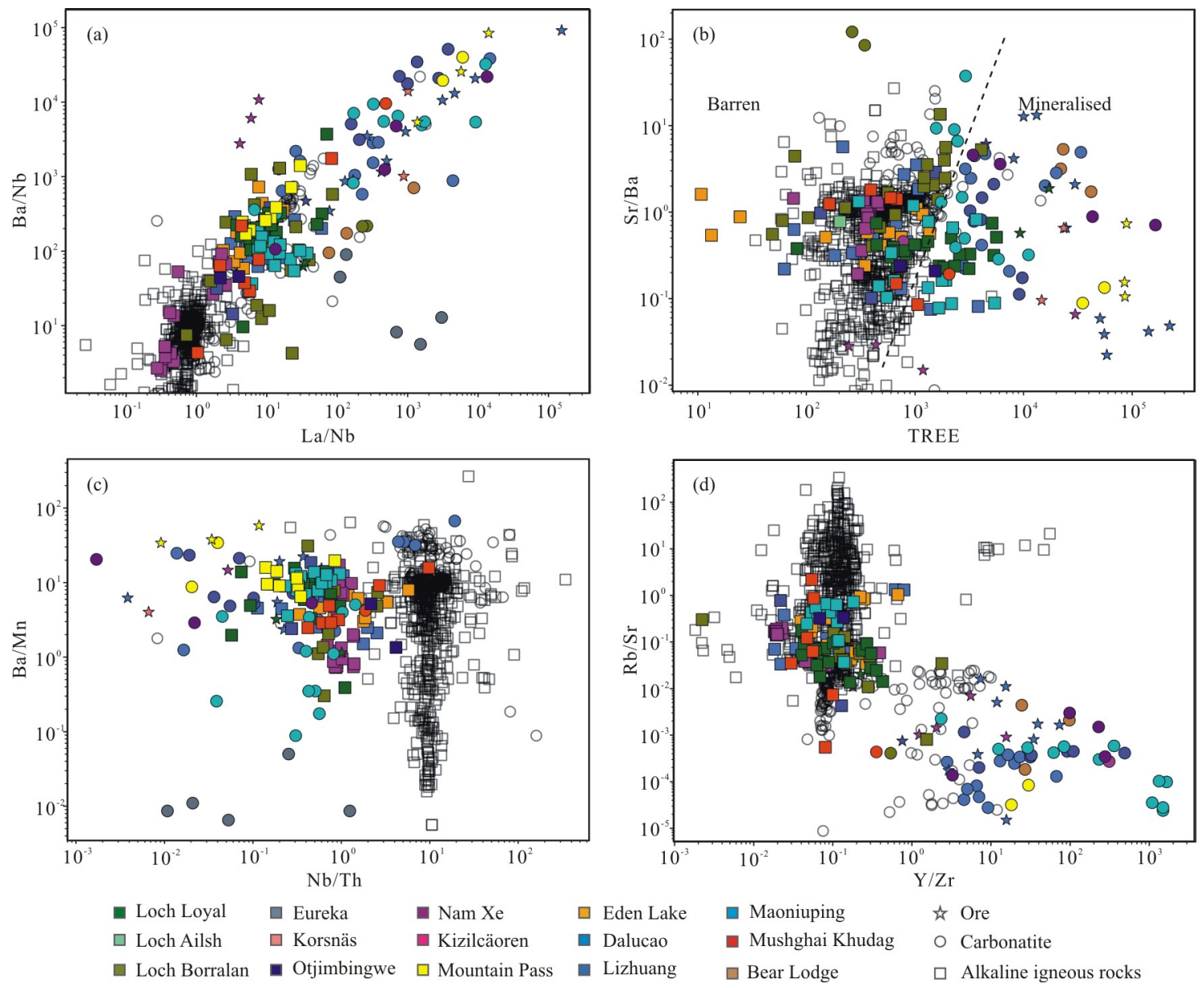

Figure 9. Selected binary trace element ratio plots for collated samples in this paper. Previously unpublished data for Kizilcaören, Eureka and Loch Borralan from Table 1: all other post-collisional data (filled, coloured symbols) from published references cited in the text and shown in Table $\mathrm{S} 1$. (a) Ba/ $\mathrm{Nb}$ vs. La/ $\mathrm{Nb}$; (b) $\mathrm{Sr} / \mathrm{Ba}$ vs. REE; (c) Ba/Mn vs. Nb/Th; and (d) Rb/Sr vs. Y/Zr. Barren/mineralized boundary for carbonatites from Liu and Hou (2017). Comparative data for the East African Rift (open symbols) downloaded from GEOROC.

(2017). Radiogenic isotope data from other post-collisional alkaline-carbonatite complexes are more limited (Table S1, Fig. 10). Typically, post-collisional alkaline-carbonatite complexes have relatively high ${ }^{87} \mathrm{Sr}^{86} \mathrm{Sr}_{(\mathrm{i})}$ and low $\varepsilon_{\mathrm{Nd}(\mathrm{i})}$. relative to complexes from continental rift settings, overlapping with the composition of EMI and EMII oceanic island basalts (Zindler and Hart, 1986). Within the Mianning-Dechang belt, the Maoniuping carbonatites have a limited and distinct range of ${ }^{87} \mathrm{Sr}^{86} \mathrm{Sr}_{(\mathrm{i})}$, and wider range of $\varepsilon_{\mathrm{Nd}(\mathrm{i})}$, indicating that this system tapped a source with a limited range of time-integrated $\mathrm{Rb} / \mathrm{Sr}$, and wider range of $\mathrm{Sm} / \mathrm{Nd}$ (Fig. 10). Other complexes have a wider range of ${ }^{87} \mathrm{Sr} /{ }^{86} \mathrm{Sr}_{(\mathrm{i})}$, but typically have a limited range in $\varepsilon_{\mathrm{Nd}(\mathrm{i})}$. The exception is the Loch Borralan Complex, where the alkaline rocks show significant $\varepsilon_{\mathrm{Nd}(\mathrm{i})}$ variation that may indicate crustal contamination. In general, the restricted isotopic ranges within each complex are incompatible with variable contributions from continental crust via assimilation during magma ascent, instead suggesting that evolved isotopic components are incorporated into the mantle source. Such compositions may reflect contributions from sediments recycled through subduction zones (Hou et al., 2015). Reviews of boron and sulfur isotope data for alkaline rocks and carbonatites more generally indicate contributions from recycled continental material
(Hutchison et al., 2019; Hulett et al., 2016).

\subsection{Post-Collisional Alkaline-Carbonatite Mineral Systems}

From the information above, it is evident that alkalinecarbonatite complexes were emplaced at the post-collisional stage in many of the world's major orogenic belts, and that many of those complexes are enriched in REE, notably the light REE. In this discussion, we consider the key features of the mineral system at province- and district-scale in order to identify the critical processes governing REE mineralization in these post-collisional mineral systems (Banks et al., 2019; McCuaig et al., 2010).

\subsubsection{Province-scale}

Critical processes for formation of REE deposits associated with post-collisional alkaline-carbonatite complexes at the province scale must include (1) an enriched source for magmas, (2) crustal-scale pathways for magmatic emplacement, and (3) erosion to a suitable level (Banks et al., 2019).

Major orogenic belts that host such deposits include the Paleoproterozoic trans-Hudson Orogen, the Pan-African orogens (e.g., the Damara belt), the Central Asian Orogenic Belt, the Tethyan-Himalayan Orogen and the Laramide Orogen. Notably, the ca. 1800 Ma trans-Hudson Orogen is considered 


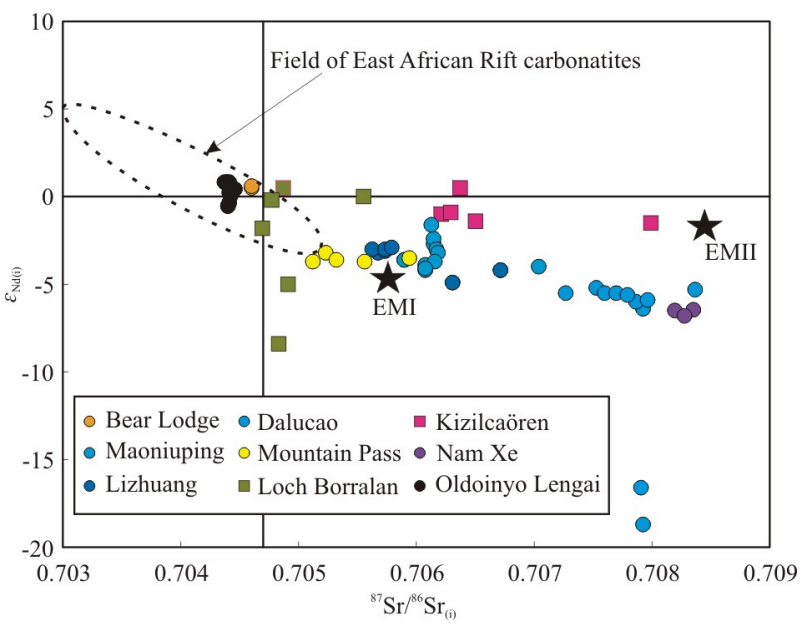

Figure 10. Published $\mathrm{Nd}$ and $\mathrm{Sr}$ isotope data for collated samples in this paper. Field of East African Rift carbonatites after Bell and Tilton (2001).

to be one of the earliest orogens to have formed through modern-style subduction processes, and is often suggested as analogous to the Tethyan-Himalayan Orogen in scale and complexity (Weller and St-Onge, 2017). The group of orogenic belts hosting post-collisional REE deposits includes both collisional and accretionary orogens (following the definition of Cawood et al., 2009), suggesting that there is no easy way to define which orogenic belts are most likely to be prospective for this type of REE deposit. However, the identified geochemical features of these alkaline-carbonatite complexes (high $\mathrm{K}, \mathrm{Th}, \mathrm{Ba}$ and $\mathrm{Sr}$; low $\mathrm{Nb}$ and $\mathrm{Ta}$ ) are consistent with formation from magmas derived by melting of a lithospheric mantle source, which has been metasomatized by fluids derived from subducted sediment (Fowler and Rollinson, 2012). Such metasomatism leads to the formation of phlogopite-rich layers and veins in the mantle (Förster et al., 2020) which subsequently undergo low-degree partial melting to generate parental alkaline magmas. Therefore any orogenic belt in which crustal materials such as sediments have been subducted beneath a continental mass, has the potential for an appropriate lithospheric mantle source to be present at depth. The highest REE contents in oceanic sediments are found in areas of very low sedimentation rate (Yasukawa et al., 2016; Plank, 2014), suggesting that one scenario for REE enrichment occurs where relatively extensive and long-lasting oceans have eventually been consumed by subduction. Such a model has been demonstrated for the alkaline-carbonatite complexes of the Mianning-Dechang belt (Hou et al., 2015). Low-degree partial melting of the metasomatized lithospheric mantle source is typically considered as an important stage in the generation of alkaline and carbonatite magmas, although it should be noted that similar results can be achieved by preferential melting of the metasomatic veins within the mantle (Pilet et al., 2008). Thus, the chemistry of post-collisional alkaline-carbonatite magmatism is controlled by a combination of an enriched mantle source, and by a low-degree melting process that preferentially releases the large ion lithophile elements.

Emplacement of post-collisional mantle-derived magmas is often associated with the change from collisional tectonics towards orogenic relaxation and extension, and the reactivation of major crustal-scale structures as transcurrent shear zones (Liu et al., 2015; Florisbal et al., 2012; Küster and Harms, 1998). Development of such structures, providing magmatic pathways, is a critical process for the formation of postcollisional alkaline-carbonatite complexes. Finally, the level of erosion of the orogenic belt is clearly important in ensuring that the mineralized zone within the alkaline-carbonatite complex is preserved and accessible.

\subsubsection{District-scale (a single alkaline-carbonatite complex)}

Combining the case-studies and examples mentioned above allows us to build up an impression of the mid- to uppercrustal parts of the 3D structure of a post-collisional alkalinecarbonatite magmatic system (Fig. 11). The deeper parts of similar systems have been described by Holwell et al. (2019). Namibia provide excellent examples of the mid- to uppercrustal magma chamber (a few km deep) within such a system. This part of the magmatic system preserves a record of the processes that have led to REE enrichment, although the main mineralization may be at higher levels. The lithologies in these parts of the complexes are typically monzodiorite, monzonite and syenite, and may be locally silica under- or over-saturated. Mafic-ultramafic rocks (typically pyroxenites and amphibolites) may be present, often as marginal bodies (as at Loch Borralan) that may represent wall cumulates.

Three critical processes may operate at this level of the system to enrich the REEs: (1) fractional crystallization, (2) melt/fluid immiscibility, and (3) metasomatism (fenitization).

Petrological and geochemical data, particularly the lack of negative $\mathrm{Eu}$ and $\mathrm{Sr}$ anomalies, are consistent with fractionation of clinopyroxene and amphibole, but not of plagioclase or $\mathrm{K}$-feldspar, in the evolution of these magmatic systems. This is consistent with major element trends across the whole dataset that indicate a negative correlation of $\mathrm{CaO}, \mathrm{MgO}$, and $\mathrm{Fe}_{2} \mathrm{O}_{3}$ with $\mathrm{SiO}_{2}$, but no clear correlation between $\mathrm{SiO}_{2}$ and $\mathrm{K}_{2} \mathrm{O}$ (Fig. 7). Suppression of plagioclase fractionation typically indicates hydrous parental magmas (Müntener et al., 2001), as might be expected for magmas derived from a source in metasomatized lithospheric mantle (Richards, 2011). The lack of plagioclase and $\mathrm{K}$-feldspar fractionation enables retention of $\mathrm{Sr}$ and $\mathrm{Ba}$ in the more evolved magmas.

The REEs are often described as being incompatible in the majority of mineral phases present in evolved potassic igneous systems, and therefore expected to show the greatest enrichment in the most fractionated compositions (Fedele et al., 2015). However, recent work demonstrates that clinopyroxene and amphibole have relatively high mineral-melt partition coefficients for the REEs, and are saturated throughout the entire magmatic differentiation series of many alkaline silicate systems (Bernard et al., 2020; Beard et al., 2019; Möller and Williams-Jones, 2016; Marks and Markl, 2001). Because of their affinity for the REEs, the composition and relative abundance of these minerals exerts a strong control on the absolute REE content and REE pattern of the residual melt (Beard et al., 2019; Vasyukova and WilliamsJones, 2019). Where these mineral phases fractionate early in the differentiation history of alkaline magmatic systems, they exert a major control on the potential for, and character of, mineralization in the later and most fractionated igneous rocks and 


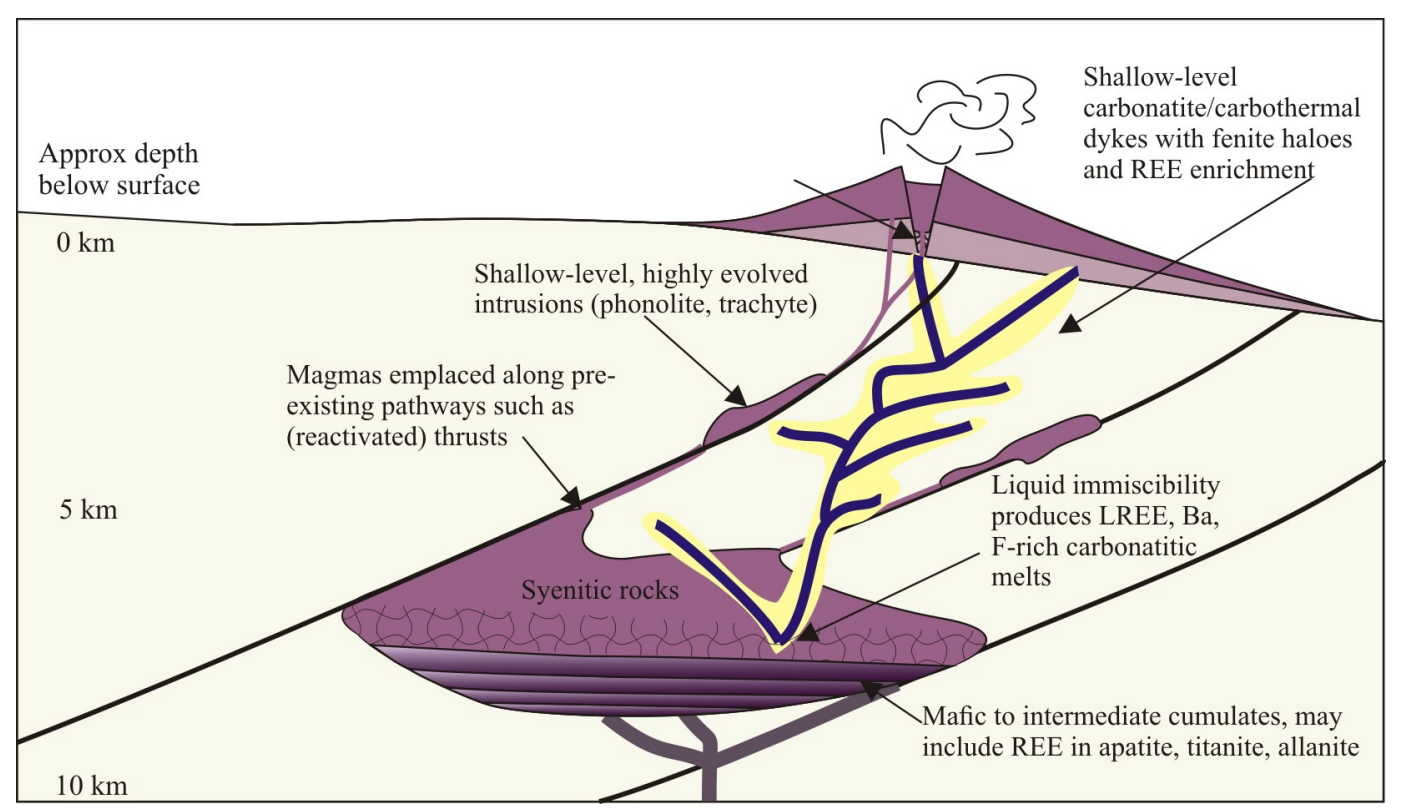

Figure 11. Schematic cartoon of the structure of an upper-crustal post-collisional alkaline-carbonatite system. Not to scale, although approximate and generalized depths are indicated.

hydrothermal alteration assemblages. However, volatile elements dissolved within the melt, such as fluorine and sulphur, can affect both phase relations of the crystallizing assemblage and the activity of REEs in silicate melt (Beard et al., 2020). Derivation of melt from sources that are rich in volatiles can thus promote the residual enrichment of metals in alkalinecarbonatite magmatic systems.

Oxygen fugacity has a role in controlling fractionating assemblages in alkaline magmas, and more potassic magmas in post-collisional settings are typically oxidized, thus producing miaskitic mineral assemblages (Marks et al., 2011; Markl et al., 2010). In these systems, the saturation of accessory phases such as allanite and titanite can effectively halt residual REE enrichment (Prowatke and Klemme, 2005; Hoskin et al., 2000). Titanite and allanite are present in intermediate lithologies such as monzodiorite and monzonite, for example at Loch Loyal in Scotland (Hughes et al., 2013; Walters et al., 2013) and Otjimbingwe in Namibia (Jung et al., 2020b). Such intermediate lithologies may therefore show higher REE contents than the most evolved compositions, syenitic or granitic, in post-collisional alkaline igneous complexes.

Overall, it is clear that fractional crystallization is important for the geochemical evolution of alkaline-carbonatite systems, but it does not consistently result in residual enrichment of the REE in the most evolved magmas. In post-collisional settings, high volatile contents in magmas may promote retention of the REE in the melt; but the oxidized nature of the magmas can lead to the formation of accessory phases that sequester the REE. The occurrence, and timing, of melt or fluid immiscibility is thus critical in the formation of REE deposits in these settings (Vigneresse et al., 2021).

Proving the occurrence of melt or fluid immiscibility in any given magmatic system is challenging as direct evidence is commonly overprinted by the passage of later fluids or melts. However, there is increasing consensus that many carbonatites form as immiscible melts within alkaline silicate magmatic systems. Ele- ment partitioning experiments between immiscible carbonate and silicate melts indicate that $\mathrm{Ba}$ strongly favours the carbonatite phase ( $D=1.5-21$, Nabyl et al., 2020; Veksler et al., 1998; Jones et al., 1995). Mn also favours carbonatite melt, but its partitioning is characterized by lower $D$ values $(D=1.2-8)$, resulting in carbonatites with higher $\mathrm{Ba} / \mathrm{Mn}$ than equilibrium silicate melts. Rare earth element partitioning is strongly dependent on the degree of fractionation and temperature, with primitive compositions (975 ${ }^{\circ} \mathrm{C}$ ) characterized by $D$ values close to unity, and evolved phonolitic compositions $\left(725^{\circ} \mathrm{C}\right)$ favouring REE incorporation into the carbonatite melt ( $D_{\mathrm{La}} \sim 50, D_{\mathrm{Lu}} \sim 6$, Nabyl et al., 2020). LREEs favour the carbonatite melt phase more strongly than the HREEs. This experimental work is broadly consistent with the geochemistry of post-collisional complexes reviewed here, in which the LREEs and $\mathrm{Ba}$ are most typically enriched in the carbonatite components, whereas $\mathrm{Nb}, \mathrm{Ta}, \mathrm{Zr}$ and $\mathrm{Hf}$ are enriched in the associated, evolved alkaline magmatic components.

However they are formed, it is evident that carbonatites and their associated fluids (or carbothermal residua, as defined by Mitchell (2005)) represent a vital part of the REE mineralizing system in post-collisional alkaline-carbonatite complexes. The best-studied of all such complexes is the Maoniuping REE deposit, where syenites are cross-cut by an extensive network of ore veins that variously contain bastnäsite, calcite, fluorite, barite, sulphides, and biotite, alkali amphiboles and alkali pyroxenes (Liu Y et al., 2019; Zheng and Liu, 2019). At greater depths, the lower levels of these veins are dominated by aegirine-augite and biotite, but lack REE mineralization (Liu and Hou, 2017).

In the Cnoc nan Cuilean intrusion (Loch Loyal Syenite Complex, NW Scotland), coarse-grained highly altered veins within the syenitic rocks contain biotite, magnetite, apatite, allanite, barite, strontianite and bastnäsite, and have the highest REE contents in the complex (Walters et al., 2013). Alteration of alkaline silicate rocks to actinolite in association with barite, strontianite and celestine is also recognized in the Loch Borra- 
lan Complex, which is associated with a carbonatite stock. Pegmatitic veins and segregations with a similar mineral assemblage of aegirine-augite, titanite, britholite, allanite, apatite, fluorite, and zircon have been described in the Eden Lake Complex (Arden and Halden, 1999), where carbonatites have also been described (Chakhmouradian et al., 2008). By comparison with the deeper levels of the vein system in Maoniuping, it seems clear that the veins rich in silicate minerals with allanite and apatite represent alteration zones that were pathways for carbonatitic melts ascending to higher levels. The extent of alteration indicates that fluids rich in alkali elements, REEs, $\mathrm{Ba}, \mathrm{Sr}$, carbonate and sulphate were expelled from the carbonatites during ascent. This process of metasomatism, or fenitization, can represent an important exploration tool for REE mineralization (Elliott et al., 2018).

The way in which the monazite-rich dolomite carbonatite dykes at Eureka fit into a generalized model is somewhat enigmatic. At present, the emplacement depth of Eureka is not quantified. Strontium isotope analyses indicate a mantle origin (Dunai et al., 1989) and the carbonatites are likely to have ascended through the crust along the Welwitschia and Omaruru lineaments. These lineaments represent large scale shear zones up to $30 \mathrm{~km}$ in width (Corner, 2008). Of these, the Omaruru lineament extends to at least $14 \mathrm{~km}$ depth, and probably merges into a mid-crustal detachment zone thereafter (Weckmann et al., 2003). These features suggest the carbonatite dykes may be a preserved conduit of carbonatite derived from immiscibility in a deeper magma chamber or potentially, directly derived from the mantle. Similar monazite-rich carbonatite dykes, emplaced into major transtensional faults, have been described from the Yangibana ore district in Australia (Slezak et al., 2021).

Some of the most significant examples of REE mineralization occur at the shallowest levels of the system (emplaced within $1 \mathrm{~km}$ of the surface), associated with brittle deformation and brecciation. At Kizilcaören, as described above, the main REE ore material comprises barite, fluorite and bastnäsite and represents an example of 'carbothermal residua'. Such mineralogy is characteristic of the hydrothermal mineralization recognized at Maoniuping (Zheng and Liu, 2019). The mineralizing fluids at Maoniuping were rich in sulphate, fluoride, chloride and carbonate as well as barium and the REE. These fluids are considered to have been originally derived from the alkaline-carbonatite magmatic system, with subsequent cooling, reaction with wall-rock, and mixing with meteoric water facilitating the precipitation of REE carbonates in association with barite and fluorite (Zheng and Liu, 2019). Similar features have been described in the Gallinas Mountains deposit (Williams-Jones et al., 2000). Thus, the emplacement of these fluids to shallow levels where they cool and mix with meteoric water is a major control on the deposition of the REE in these systems.

Overall, our review indicates the following critical processes for REE mineralization at the scale of a single postcollisional alkaline-carbonatite complex: (1) fractional crystallization in a mid- to upper-crustal magma chamber, producing evolved, trachytic to phonolitic alkaline silicate magmas; (2) formation of an immiscible carbonatite melt and/or fluids, into which $\mathrm{Ba}$, the LREE and volatile elements preferentially partition; (3) ascent of the carbonatite to shallow crustal levels, following structural pathways, with expulsion of fenitizing fluids and mixing with meteoric/ basinal fluids controlling the eventual emplacement of 'carbothermal' ore bodies that are typically rich in barite, fluorite and REE carbonate.

\subsection{Comparison with Alkaline-Carbonatite Complexes in Rift-Related Settings}

Despite the excellent work by many teams working on post-collisional alkaline-carbonatite complexes, particularly in China (Jia and Liu, 2020; Liu and Hou, 2017; Hou et al., 2015, 2009) there is still a widespread expectation that most REE deposits associated with alkaline rocks and carbonatites will be found in intracontinental and rift-related settings (Dostal, 2017). In reality, although alkaline igneous complexes in such settings may be very large, the most significant REE grades are typically found in the agpaitic, peralkaline lithologies, which have extremely complex mineralogy and geometallurgy (Marks and Markl, 2017). Carbonatites in intracontinental settings have been well-studied, but in many cases the REE enrichments are concentrated in late-stage ferrocarbonatite sheets or irregular zones of late-stage alteration that may only make up a small part of the whole intrusion (Dietzel et al., 2019; Wall and Mariano, 1995). Thus, although intracontinental and rift-related alkalinecarbonatite complexes will undoubtedly provide some of the world's future REE supply, many of the world's currently mined hard-rock REE deposits have formed in post-collisional settings. A clear exception is the intracontinental carbonatite at Mt Weld in Australia, where the REE deposit has been upgraded by weathering (Spandler et al., 2020).

Post-collisional alkaline-carbonatite complexes are characterized by an association of the REE minerals with potential by-products such as barite, fluorite, and manganese oxides. In contrast, rift-related carbonatites and alkaline complexes commonly have the potential for $\mathrm{Nb}$ as a by-product. Our collated geochemical data clearly indicate that this is not the case in post-collisional settings, where carbonatites are characterized by notably lower $\mathrm{Nb}$ and higher LREE contents. In comparison with data from the East African Rift, post-collisional alkalinecarbonatite complexes have relatively high $\mathrm{K}, \mathrm{Ba}$, Th, Sr, LREE and $\mathrm{F}$, but low $\mathrm{Nb}$ and $\mathrm{Ta}$ concentrations. Such geochemical features are consistent with a parental lithospheric mantle source that has been metasomatized by fluids or melts derived from crustal materials in a subducting slab (Zanetti et al., 1999).

It is worth noting that in some cases, it seems that postcollisional melting of the metasomatized lithospheric mantle has not taken place (Förster et al., 2020) and the metasomes can be preserved for hundreds of millions of years before melting. An example of this type of situation comes from the Gardar Province of SW Greenland, a Mesoproterozoic rift where REE-enriched alkaline-carbonatite magmas are derived from lithospheric mantle sources that were metasomatized during Paleoproterozoic subduction (Bartels et al., 2015; Goodenough et al., 2002). Thus, there is potential for some rift settings to also show features of post-collisional alkaline-carbonatite magmatism.

\section{CONCLUSIONS}

This review shows that many of the most important REE deposits worldwide are in syn- to post-collisional alkaline- 
carbonatite complexes. In these complexes, REE enrichment is commonly associated with barite and fluorite mineralization, but notably with low $\mathrm{Nb}$ contents. Taking a mineral systems approach, critical targeting criteria for post-collisional REE deposits are as follows.

Province-scale: (1) evidence in the geological history for a lithospheric mantle source that has been enriched by subduction of marine sediments; (2) reactivation of collisional structures as transcurrent shear zones that provide transcrustal ascent pathways for magmas; and (3) appropriate levels of erosion to ensure preservation of deposits.

District-scale: (1) fractional crystallization of mafic alkaline magmas in a mid- to upper-crustal magmatic system, producing evolved magmatic compositions that are residually enriched in REE; (2) immiscibility of carbonatite melts, which Ba, F and the LREE preferentially partition into; (3) emplacement of the carbonatite melts at shallower crustal levels, with associated carbothermal fluid circulation and metal deposition. This shallow-level carbonatitic system represents the major zone of REE mineralization in these complexes.

Post-collisional alkaline-carbonatite complexes with REE mineralization occur in orogenic belts on all continents and have formed since the Palaeoproterozoic. Our review highlights that such mineralization can be generated by a relatively common sequence of processes, and hence that targeted exploration may identify further extensive REE mineralization belts similar to the well-studied Cenozoic Mianning-Dechang Belt in China.

\section{ACKNOWLEDGMENTS}

This research was supported by the European Union's Horizon 2020 research and innovation programme through the HiTech AlkCarb Project (No. 689909). Sam Broom-Fendley acknowledges a Natural Environment Research Council (NERC) Industrial Innovation Fellowship (No. NE/R013403/1). Kathryn M. Goodenough and Eimear A. Deady publish with the permission of the Director of the British Geological Survey. Martin Gillespie and two anonymous reviewers are greatly thanked for their constructive and thoughtful comments, which have greatly improved the manuscript. The final publication is available at Springer via https://doi.org/10.1007/s12583-021-1312-7.

Electronic Supplementary Materials: Supplementary materials (Table S1) are available in the online version of this article at https://doi.org/10.1007/s12583-021-1500-5.

Open Access This article is licensed under a Creative Commons Attribution 4.0 International License, which permits use, sharing, adaptation, distribution and reproduction in any medium or format, as long as you give appropriate credit to the original author(s) and the source, provide a link to the Creative Commons licence, and indicate if changes were made. The images or other third party material in this article are included in the article's Creative Commons licence, unless indicated otherwise in a credit line to the material. If material is not included in the article's Creative Commons licence and your intended use is not permitted by statutory regulation or exceeds the permitted use, you will need to obtain permission directly from the copyright holder. To view a copy of this licence, visit http://creativecommons.org/licenses/by/4.0/.

\section{REFERENCES CITED}

Al-Ani, T., 2013. Mineralogy and Petrography of Siilinjärvi Carbonatite and Glimmerite Rocks, Eastern Finland. Geological Survey of Finland Report, 164

Al-Ani, T., Molnár, F., Lintinen, P., et al., 2018. Geology and Mineralogy of Rare Earth Elements Deposits and Occurrences in Finland. Minerals, 8(8): 356. https://doi.org/10.3390/min 8080356

Allsopp, H., Kostlin, E., Welke, H., et al., 1979. Rb-Sr and U-Pb Geochronology of Late Precambrian-Early Palaeozoic Igneous Activity in the Richtersveld (South Africa) and Southern South West Africa. Transactions of the Geological Society of South Africa, 82(2): 185-204

Andersen, A. K., Clark, J. G., Larson, P. B., et al., 2016. Mineral Chemistry and Petrogenesis of a HFSE(+HREE) Occurrence, Peripheral to Carbonatites of the Bear Lodge Alkaline Complex, Wyoming. American Mineralogist, 101(7): 1604-1623. https://doi.org/10.2138/am-2016-5532

Arden, K. M., Halden, N. M., 1999. Crystallization and Alteration History of Britholite in Rare-Earth-Element-Enriched Pegmatitic Segregations Associated with the Eden Lake Complex, Manitoba, Canada. The Canadian Mineralogist, 37(5): 1239-1253

Baatar, M., Ochir, G., Kynicky, J., et al., 2013. Some Notes on the Lugiin Gol, Mushgai Khudag and Bayan Khoshuu Alkaline Complexes, Southern Mongolia. International Journal of Geosciences, 4(8): 1200-1214. https://doi.org/10.4236/ijg.2013.48114

Banks, G., Walter, B., Marks, M., et al., 2019. A Workflow to Define, Map and Name a Carbonatite- or Alkaline Igneous-Associated REE-HFSE Mineral System: A Case Study from SW Germany. Minerals, 9(2): 97. https://doi.org/10.3390/min9020097

Bartels, A., Nielsen, T. F. D., Lee, S. R., et al., 2015. Petrological and Geochemical Characteristics of Mesoproterozoic Dyke Swarms in the Gardar Province, South Greenland: Evidence for a Major Sub-Continental Lithospheric Mantle Component in the Generation of the Magmas. Mineralogical Magazine, 79(4): 909-939. https://doi.org/10.1180/minmag.2015.079.4.04

Be'eri-Shlevin, Y., Katzir, Y., Whitehouse, M., 2009. Post-Collisional Tectonomagmatic Evolution in the Northern Arabian-Nubian Shield: Time Constraints from Ion-Probe U-Pb Dating of Zircon. Journal of the Geological Society, 166(1): 71-85. https://doi.org/10.1144/0016-76492007-169

Beard, C. D., van Hinsberg, V. J., Stix, J., et al., 2019. Clinopyroxene/Melt Trace Element Partitioning in Sodic Alkaline Magmas. Journal of Petrology, 60(9): 1797-1823. https://doi.org/10.1093/petrology/egz052

Beard, C. D., Hinsberg, V. J., Stix, J., et al., 2020. The Effect of Fluorine on Clinopyroxene/Melt Trace-Element Partitioning. Contributions to Mineralogy and Petrology, 175(5): 1-19. https://doi.org/10.1007/s00410-020-1672-5

Bell, K., Tilton, G. R., 2001. Nd, Pb and Sr Isotopic Compositions of East African Carbonatites: Evidence for Mantle Mixing and Plume Inhomogeneity. Journal of Petrology, 42(10): 1927-1945. https://doi.org/10.1093/petrology/42.10.1927

Bernard, C., Estrade, G., Salvi, S., et al., 2020. Alkali Pyroxenes and Amphiboles: A Window on Rare Earth Elements and other High Field Strength Elements Behavior through the Magmatic-Hydrothermal Transition of Peralkaline Granitic Systems. Contributions to Mineralogy and Petrology, 175(9): 1-27. https://doi.org/10.1007/s00410-020-01723-y

Bianchini, G., Beccaluva, L., Siena, F., 2008. Post-Collisional and Intraplate Cenozoic Volcanism in the Rifted Apennines/Adriatic Domain. Lithos, 
101(1/2): 125-140. https://doi.org/10.1016/j.lithos.2007.07.011

Black, R., Lameyre, J., Bonin, B., 1985. The Structural Setting of Alkaline Complexes. Journal of African Earth Sciences, 3(1/2): 5-16. https://doi.org/10.1016/0899-5362(85)90019-3

Blichert-Toft, J., Arndt, N. T., Ludden, J. N., 1996. Precambrian Alkaline Magmatism. $\quad$ Lithos, 37(2/3): 97-111. https://doi.org/10.1016/0024-4937(95)00031-3

Bonin, B., 2004. Do Coeval Mafic and Felsic Magmas in Post-Collisional to Within-Plate Regimes Necessarily Imply Two Contrasting, Mantle and Crustal, Sources? A Review. Lithos, 78(1/2): 1-24. https://doi.org/10.1016/j.lithos.2004.04.042

Bonin, B., 2007. A-Type Granites and Related Rocks: Evolution of a Concept, Problems and Prospects. Lithos, 97(1/2): 1-29. https://doi.org/10.1016/j.lithos.2006.12.007

Broom-Fendley, S., Smith, M. P., Andrade, M. B., et al., 2020. Sulfur-Bearing Monazite-(Ce) from the Eureka Carbonatite, Namibia: Oxidation State, Substitution Mechanism, and Formation Conditions. Mineralogical Magazine, 84(1): 35-48. https://doi.org/10.1180/mgm.2019.79

Buyse, F., Dewaele, S., Decrée, S., et al., 2020. Mineralogical and Geochemical Study of the Rare Earth Element Mineralization at Gakara (Burundi). Ore Geology Reviews, 124: 103659. https://doi.org/10.1016/j.oregeorev.2020.103659

Castor, S. B., 2008. The Mountain Pass Rare-Earth Carbonatite and Associated Ultrapotassic Rocks, California. The Canadian Mineralogist, 46(4): 779-806. https://doi.org/10.3749/canmin.46.4.779

Cawood, P. A., Kröner, A., Collins, W. J., et al., 2009. Accretionary Orogens through Earth History. Geological Society London Special Publications, 318(1): 1-36. https://doi.org/10.1144/sp318.1

Chakhmouradian, A. R., Mumin, A. H., Demény, A., et al., 2008. Postorogenic Carbonatites at Eden Lake, Trans-Hudson Orogen (Northern Manitoba, Canada): Geological Setting, Mineralogy and Geochemistry. Lithos, 103(3/4): 503-526. https://doi.org/10.1016/j.lithos.2007.11.004

Chakhmouradian, A. R., Zaitsev, A. N., 2012. Rare Earth Mineralization in Igneous Rocks: Sources and Processes. Elements, 8(5): 347-353

Chen, B., Jahn, B. M., 2004. Genesis of Post-Collisional Granitoids and Basement Nature of the Junggar Terrane, NW China: Nd-Sr Isotope and Trace Element Evidence. Journal of Asian Earth Sciences, 23(5): 691-703. https://doi.org/10.1016/s1367-9120(03)00118-4

Chung, S.-L., Chu, M.-F., Zhang, Y., et al., 2005. Tibetan Tectonic Evolution Inferred from Spatial and Temporal Variations in Post-Collisional Magmatism. Earth-Science Reviews, 68(3/4): 173-196. https://doi.org/10.1016/j.earscirev.2004.05.001

Çimen, O., Corcoran, L., Kuebler, C., et al., 2020. Geochemical, Stable (O, $\mathrm{C}$, and $\mathrm{B}$ ) and Radiogenic $(\mathrm{Sr}, \mathrm{Nd}, \mathrm{Pb})$ Isotopic Data from the Eskişehir-Kızılcaören (NW-Anatolia) and the Malatya-Kuluncak (E-central Anatolia) F-REE-Th Deposits, Turkey: Implications for Nature of Carbonate-Hosted Mineralization. Turkish Journal of Earth Sciences, 29(5): 798-814

Çimen, O., Kuebler, C., Monaco, B., et al., 2018. Boron, Carbon, Oxygen and Radiogenic Isotope Investigation of Carbonatite from the Miaoya Complex, Central China: Evidences for Late-Stage REE Hydrothermal Event and Mantle Source Heterogeneity. Lithos, 322: 225-237. https://doi.org/10.1016/j.lithos.2018.10.018

Corner, B., 2008. Crustal Framework of Namibia Derived from an Integrated Interpretation of Geophysical and Geological Data. Communs. Geol. Surv. Namibia, 12: 15-22

Couzinié, S., Laurent, O., Moyen, J. F., et al., 2016. Post-Collisional Magmatism: Crustal Growth not Identified by Zircon Hf-O Isotopes.
Earth and Planetary Science Letters, 456: 182-195. https://doi.org/10.1016/j.eps1.2016.09.033

Deady, E., Lacinska, A., Goodenough, K., et al., 2019. Volcanic-Derived Placers as a Potential Resource of Rare Earth Elements: The Aksu Diamas Case Study, Turkey. Minerals, 9(4): 208. https://doi.org/10.3390/min9040208

Decrée, S., Savolainen, M., Mercadier, J., et al., 2020. Geochemical and Spectroscopic Investigation of Apatite in the Siilinjärvi Carbonatite Complex: Keys to Understanding Apatite Forming Processes and Assessing Potential for Rare Earth Elements. Applied Geochemistry, 123: 104778. https://doi.org/10.1016/j.apgeochem.2020.104778

Dietzel, C. A. F., Kristandt, T., Dahlgren, S., et al., 2019. Hydrothermal Processes in the Fen Alkaline-Carbonatite Complex, Southern Norway. Ore Geology Reviews, 111: 102969. https://doi.org/10.1016/j.oregeorev.2019.102969

Dilek, Y., Altunkaynak, Ş., 2007. Cenozoic Crustal Evolution and Mantle Dynamics of Post-Collisional Magmatism in Western Anatolia. International Geology Review, 49(5): 431-453. https://doi.org/10.2747/0020-6814.49.5.431

Dilek, Y., Altunkaynak, Ş., 2009. Geochemical and Temporal Evolution of Cenozoic Magmatism in Western Turkey: Mantle Response to Collision, Slab Break-off, and Lithospheric Tearing in an Orogenic Belt. Geological Society Special Publication, 311: 213-233. https://doi.org/10.1144/sp311.8

Dostal, J., 2017. Rare Earth Element Deposits of Alkaline Igneous Rocks. Resources, 6(3): 34. https://doi.org/10.3390/resources6030034

Dunai, T., Stoessel, G., Ziegler, U., 1989. Note: A Sr Isotope Study of the Eureka Carbonatite, Damaraland, Namibia. Communs. Geol. Surv. Namibia, 5: 91-92

Dunai, T. J., 1989. Petrographische, Geochemische und Lagerstättenkundliche Untersuchungen an Karbonatitgängen auf der Farm Eureka $\mathrm{Nr}$ 99: [Dissertation]. Verlag nicht ermittelbar, Damaraland, Namibia

Elliott, H. A. L., Wall, F., Chakhmouradian, A. R., et al., 2018. Fenites Associated with Carbonatite Complexes: A Review. Ore Geology Reviews, 93: 38-59. https://doi.org/10.1016/j.oregeorev.2017.12.003

Evans, D. A. D., Mitchell, R. N., 2011. Assembly and Breakup of the Core of Paleoproterozoic-Mesoproterozoic Supercontinent Nuna. Geology, 39(5): 443-446. https://doi.org/10.1130/g31654.1

Fedele, L., Lustrino, M., Melluso, L., et al., 2015. Trace-Element Partitioning between Plagioclase, Alkali Feldspar, Ti-Magnetite, Biotite, Apatite, and Evolved Potassic Liquids from Campi Flegrei (Southern Italy). American Mineralogist, 100(1): 233-249. https://doi.org/10.2138/am-2015-4995

Feng, M., Song, W. L., Kynicky, J., et al., 2020. Primary Rare Earth Element Enrichment in Carbonatites: Evidence from Melt Inclusions in Ulgii Khiid Carbonatite, Mongolia. Ore Geology Reviews, 117: 103294. https://doi.org/10.1016/j.oregeorev.2019.103294

Florisbal, L. M., Bitencourt, M. D. F., Janasi, V. D. A., et al., 2012. Petrogenesis of Syntectonic Granites Emplaced at the Transition from Thrusting to Transcurrent Tectonics in Post-Collisional Setting: Whole-Rock and $\mathrm{Sr}-\mathrm{Nd}-\mathrm{Pb}$ Isotope Geochemistry in the Neoproterozoic Quatro Ilhas and Mariscal Granites, Southern Brazil. Lithos, 153: 53-71. https://doi.org/10.1016/j.lithos.2012.04.031

Foley, S. F., Venturelli, G., Green, D. H., et al., 1987. The Ultrapotassic Rocks: Characteristics, Classification, and Constraints for Petrogenetic Models. Earth-Science Reviews, 24(2): 81-134. https://doi.org/10.1016/0012-8252(87)90001-8

Förster, M. W., Buhre, S., Xu, B., et al., 2020. Two-Stage Origin of K-Enrichment in Ultrapotassic Magmatism Simulated by Melting of 
Experimentally Metasomatized Mantle. Minerals, 10(1): 41. https://doi.org/10.3390/min10010041

Fowler, M., Rollinson, H., 2012. Phanerozoic Sanukitoids from Caledonian Scotland: Implications for Archean Subduction. Geology, 40(12): 1079-1082. https://doi.org/10.1130/g33371.1

Fowler, M. B., Kocks, H., Darbyshire, D. P. F., et al., 2008. Petrogenesis of High Ba-Sr Plutons from the Northern Highlands Terrane of the British Caledonian Province. Lithos, 105(1/2): 129-148. https://doi.org/10.1016/j.lithos.2008.03.003

Freeburn, R., Bouilhol, P., Maunder, B., et al., 2017. Numerical Models of the Magmatic Processes Induced by Slab Breakoff. Earth and Planetary Science Letters, 478: 203-213. https://doi.org/10.1016/j.eps1.2017.09.008

Gardiner, N. J., Kirkland, C. L., van Kranendonk, M. J., 2016. The Juvenile Hafnium Isotope Signal as a Record of Supercontinent Cycles. Scientific Reports, 6: 38503. https://doi.org/10.1038/srep38503

Gonçalves, G. O., Lana, C., Scholz, R., et al., 2018. The Diamantina Monazite: A New Low-Th Reference Material for Microanalysis. Geostandards and Geoanalytical Research, 42(1): 25-47. https://doi.org/10.1111/ggr.12192

Goodenough, K. M., Upton, B. G. J., Ellam, R. M., 2002. Long-Term Memory of Subduction Processes in the Lithospheric Mantle: Evidence from the Geochemistry of Basic Dykes in the Gardar Province of South Greenland. Journal of the Geological Society, 159(6): 705-714. https://doi.org/10.1144/0016-764901-154

Goodenough, K. M., Millar, I., Strachan, R. A., et al., 2011. Timing of Regional Deformation and Development of the Moine Thrust Zone in the Scottish Caledonides: Constraints from the U-Pb Geochronology of Alkaline Intrusions. Journal of the Geological Society, 168(1): 99-114. https://doi.org/10.1144/0016-76492010-020

Goodenough, K. M., Schilling, J., Jonsson, E., et al., 2016. Europe's Rare Earth Element Resource Potential: An Overview of REE Metallogenetic Provinces and Their Geodynamic Setting. Ore Geology Reviews, 72: 838-856. https://doi.org/10.1016/j.oregeorev.2015.09.019

Goodenough, K. M., Wall, F., Merriman, D., 2018. The Rare Earth Elements: Demand, Global Resources, and Challenges for Resourcing Future Generations. Natural Resources Research, 27(2): 201-216. https://doi.org/10.1007/s11053-017-9336-5

Gozzi, F., Gaeta, M., Freda, C., et al., 2014. Primary Magmatic Calcite Reveals Origin from Crustal Carbonate. Lithos, 190/191: 191-203. https://doi.org/10.1016/j.lithos.2013.12.008

Griffiths, D., 2011. Metallogenesis of Rare Earth Elements in Ultramafic Rocks of the Loch Borralan Complex: [Dissertation]. University of Exeter, Exeter

Gültekin, A. H., Örgün, Y., Suner, F., 2003. Geology, Mineralogy and Fluid Inclusion Data of the Kizilcaören Fluorite-Barite-REE Deposit, Eskisehir, Turkey. Journal of Asian Earth Sciences, 21(4): 365-376. https://doi.org/10.1016/s1367-9120(02)00019-6

Guo, D. X., Liu, Y., 2019. Occurrence and Geochemistry of Bastnäsite in Carbonatite-Related REE Deposits, Mianning-Dechang REE Belt, Sichuan Province, SW China. Ore Geology Reviews, 107: 266-282. https://doi.org/10.1016/j.oregeorev.2019.02.028

Guo, Z. F., Wilson, M., Liu, J. Q., et al., 2006. Post-Collisional, Potassic and Ultrapotassic Magmatism of the Northern Tibetan Plateau: Constraints on Characteristics of the Mantle Source, Geodynamic Setting and Uplift Mechanisms. Journal of Petrology, 47(6): 1177-1220. https://doi.org/10.1093/petrology/eg1007

Halden, N. M., Fryer, B. J., 1999. Geochemical Characteristics of the Eden
Lake Complex: Evidence for Anorogenic Magmatism in the Trans-Hudson Orogen. Canadian Journal of Earth Sciences, 36(1): 91-103. https://doi.org/10.1139/e98-089

Hatzl, T., 1992. Die Genese der Karbonatit-und Alkalivulkanit-Assoziierten Fluorit-Baryt-Bastnäsit-Vererzung bei Kizilçaören (Türkei). Inst. für Allg. u. Angewandte Geologie d. Ludwig-Maximilians-Univ.

Holdsworth, R. E., McErlean, M. A., Strachan, R. A., 1999. The Influence of Country Rock Structural Architecture during Pluton Emplacement: The Loch Loyal Syenites, Scotland. Journal of the Geological Society, 156(1): 163-175. https://doi.org/10.1144/gsjgs.156.1.0163

Holwell, D. A., Fiorentini, M., McDonald, I., et al., 2019. A Metasomatized Lithospheric Mantle Control on the Metallogenic Signature of Post-Subduction Magmatism. Nature Communications, 10: 3511. https://doi.org/10.1038/s41467-019-11065-4

Hoskin, P. W. O., Kinny, P. D., Wyborn, D., et al., 2000. Identifying Accessory Mineral Saturation during Differentiation in Granitoid Magmas: an Integrated Approach. Journal of Petrology, 41(9): 1365-1396. https://doi.org/10.1093/petrology/41.9.1365

Hou, Z. Q., Tian, S. H., Yuan, Z. X., et al., 2006. The Himalayan Collision Zone Carbonatites in Western Sichuan, SW China: Petrogenesis, Mantle Source and Tectonic Implication. Earth and Planetary Science Letters, 244(1/2): 234-250. https://doi.org/10.1016/j.eps1.2006.01.052

Hou, Z. Q., Tian, S. H., Xie, Y. L., et al., 2009. The Himalayan Mianning-Dechang REE Belt Associated with Carbonatite-Alkaline Complexes, Eastern Indo-Asian Collision Zone, SW China. Ore Geology Reviews, 36(1/2/3): 65-89. https://doi.org/10.1016/j.oregeorev.2009.03.001

Hou, Z. Q., Liu, Y., Tian, S. H., et al., 2015. Formation of Carbonatite-Related Giant Rare-Earth-Element Deposits by the Recycling of Marine Sediments. Scientific Reports, 5: 10231. https://doi.org/10.1038/srep10231

Hou, Z. Q., Zhang, H. R., 2015. Geodynamics and Metallogeny of the Eastern Tethyan Metallogenic Domain. Ore Geology Reviews, 70: 346-384. https://doi.org/10.1016/j.oregeorev.2014.10.026

Hronsky, J. M. A., Groves, D. I., Loucks, R. R., et al., 2012. A Unified Model for Gold Mineralisation in Accretionary Orogens and Implications for Regional-Scale Exploration Targeting Methods. Mineralium Deposita, 47(4): 339-358. https://doi.org/10.1007/s00126-012-0402-y

Hughes, H. S. R., Goodenough, K. M., Walters, A. S., et al., 2013. The Structure and Petrology of the Cnoc Nan Cuilean Intrusion, Loch Loyal Syenite Complex, NW Scotland. Geological Magazine, 150(5): 783-800. https://doi.org/10.1017/s0016756812000957

Hulett, S. R. W., Simonetti, A., Troy Rasbury, E., et al., 2016. Recycling of Subducted Crustal Components into Carbonatite Melts Revealed by Boron Isotopes. Nature Geoscience, 9(12): 904-908. https://doi.org/10.1038/ngeo2831

Hutchison, W., Babiel, R. J., Finch, A. A., et al., 2019. Sulphur Isotopes of Alkaline Magmas Unlock Long-Term Records of Crustal Recycling on Earth. Nature Communications, 10: 4208 . https://doi.org/10.1038/s41467-019-12218-1

Ihlen, P. M., Schiellerup, H., Gautneb, H., et al., 2014. Characterization of Apatite Resources in Norway and Their REE Potential-A Review. Ore Geology Reviews, 58: 126-147. https://doi.org/10.1016/j.oregeorev.2013.11.003

Ivanov, A. V., Levitskii, I. V., Levitskii, V. I., et al., 2019. Shoshonitic Magmatism in the Paleoproterozoic of the South-Western Siberian Craton: an Analogue of the Modern Post-Collision Setting. Lithos, 328/329: 88-100. https://doi.org/10.1016/j.lithos.2019.01.015

Jia, Y. H., Liu, Y., 2020. Factors Controlling the Generation and Diversity of Giant Carbonatite-Related Rare Earth Element Deposits: Insights from the Mianning-Dechang Belt. Ore Geology Reviews, 121: 103472. 
https://doi.org/10.1016/j.oregeorev.2020.103472

Jones, J. H., Walker, D., Pickett, D. A., et al., 1995. Experimental Investigations of the Partitioning of $\mathrm{Nb}, \mathrm{Mo}, \mathrm{Ba}, \mathrm{Ce}, \mathrm{Pb}, \mathrm{Ra}, \mathrm{Th}, \mathrm{Pa}$, and $\mathrm{U}$ between Immiscible Carbonate and Silicate Liquids. Geochimica et Cosmochimica Acta, 59(7): 1307-1320. https://doi.org/10.1016/0016-7037(95)00045-2

Jung, S., Mezger, K., 2003. Petrology of Basement-Dominated Terranes: I. Regional Metamorphic T-t Path from U-Pb Monazite and Sm-Nd Garnet Geochronology (Central Damara Orogen, Namibia). Chemical Geology, 198(3/4): 223-247. https://doi.org/10.1016/s0009-2541(03)00037-8

Jung, S., Hoernes, S., Hoffer, E., 2005. Petrogenesis of Cogenetic Nepheline and Quartz Syenites and Granites (Northern Damara Orogen, Namibia): Enriched Mantle versus Crustal Contamination. The Journal of Geology, 113(6): 651-672. https://doi.org/10.1086/467475

Jung, S., Brandt, S., Bast, R., et al., 2019. Metamorphic Petrology of a High-T/ Low- $P$ Granulite Terrane (Damara Belt, Namibia) Constraints from Pseudosection Modelling and High-Precision Lu-Hf Garnet-Whole Rock Dating. Journal of Metamorphic Geology, 37(1): 41-69. https://doi.org/10.1111/jmg.12448

Jung, S., Hauff, F., Berndt, J., 2020a. Generation of a Potassic to Ultrapotassic Alkaline Complex in a Syn-Collisional Setting through Flat Subduction: Constraints on Magma Sources and Processes (Otjimbingwe Alkaline Complex, Damara Orogen, Namibia). Gondwana Research, 82: 267-287. https://doi.org/10.1016/j.gr.2020.01.004

Jung, S., Pfänder, J. A., Hauff, F., et al., 2020b. Crust-Mantle Interaction during Syn-Collisional Magmatism-Evidence from the Oamikaub Diorite and Neikhoes Metagabbro (Damara Orogen, Namibia). Precambrian Research, 351: 105955. https://doi.org/10.1016/j.precamres.2020.105955

Kelley, K. D., Ludington, S., 2002. Cripple Creek and Other Alkaline-Related Gold Deposits in the Southern Rocky Mountains, USA: Influence of Regional Tectonics. Mineralium Deposita, 37(1): 38-60. https://doi.org/10.1007/s00126-001-0229-4

Kim, N., Cheong, A. C. S., Yi, K., et al., 2016. Post-Collisional Carbonatite-Hosted Rare Earth Element Mineralization in the Hongcheon Area, Central Gyeonggi Massif, Korea: Ion Microprobe Monazite U-Th-Pb Geochronology and Nd-Sr Isotope Geochemistry. Ore Geology Reviews, 79: 78-87. https://doi.org/10.1016/j.oregeorev.2016.05.016

Kim, S. W., Oh, C. W., Williams, I. S., et al., 2006. Phanerozoic High-Pressure Eclogite and Intermediate-Pressure Granulite Facies Metamorphism in the Gyeonggi Massif, South Korea: Implications for the Eastward Extension of the Dabie-Sulu Continental Collision Zone. Lithos, 92(3/4): 357-377. https://doi.org/10.1016/j.lithos.2006.03.050

Küster, D., Harms, U., 1998. Post-Collisional Potassic Granitoids from the Southern and Northwestern Parts of the Late Neoproterozoic East African Orogen: A Review. Lithos, 45(1/2/3/4): 177-195. https://doi.org/10.1016/s0024-4937(98)00031-0

Küster, D., 2009. Granitoid-Hosted Ta Mineralization in the Arabian-Nubian Shield: Ore Deposit Types, Tectono-Metallogenetic Setting and Petrogenetic Framework. Ore Geology Reviews, 35(1): 68-86. https://doi.org/10.1016/j.oregeorev.2008.09.008

Lehmann, J., Saalmann, K., Naydenov, K. V., et al., 2016. Structural and Geochronological Constraints on the Pan-African Tectonic Evolution of the Northern Damara Belt, Namibia. Tectonics, 35(1): 103-135. https://doi.org/10.1002/2015tc003899

Liégeois, J. P., Navez, J., Hertogen, J., et al., 1998. Contrasting Origin of Post-Collisional High-K Calc-Alkaline and Shoshonitic versus Alkaline and Peralkaline Granitoids. the Use of Sliding Normalization. Lithos, 45(1/2/3/4): 1-28. https://doi.org/10.1016/s0024-4937(98)00023-1

Liu, C., Runyon, S. E., Knoll, A. H., et al., 2019. The Same and not the
Same: Ore Geology, Mineralogy and Geochemistry of Rodinia Assembly Versus other Supercontinents. Earth-Science Reviews, 196: 102860. https://doi.org/10.1016/j.earscirev.2019.05.004

Liu, Y., Hou, Z. Q., Tian, S. H., et al., 2015. Zircon U-Pb Ages of the Mianning-Dechang Syenites, Sichuan Province, Southwestern China: Constraints on the Giant REE Mineralization Belt and Its Regional Geological Setting. Ore Geology Reviews, 64: 554-568. https://doi.org/10.1016/j.oregeorev.2014.03.017

Liu, Y., Hou, Z. Q., 2017. A Synthesis of Mineralization Styles with an Integrated Genetic Model of Carbonatite-Syenite-Hosted REE Deposits in the Cenozoic Mianning-Dechang REE Metallogenic Belt, the Eastern Tibetan Plateau, Southwestern China. Journal of Asian Earth Sciences, 137: 35-79. https://doi.org/10.1016/j.jseaes.2017.01.010

Liu, Y., Chakhmouradian, A. R., Hou, Z. Q., et al., 2019. Development of REE Mineralization in the Giant Maoniuping Deposit (Sichuan, China) Insights from Mineralogy, Fluid Inclusions, and Trace-Element Geochemistry. Mineralium Deposita, 54(5): 701-718. https://doi.org/10.1007/s00126-018-0836-y

Longridge, L., Gibson, R. L., Kinnaird, J. A., et al., 2017. New Constraints on the Age and Conditions of LPHT Metamorphism in the Southwestern Central Zone of the Damara Belt, Namibia and Implications for Tectonic Setting. Lithos, 278/279/280/281: 361-382. https://doi.org/10.1016/j.lithos.2017.02.006

Markl, G., Marks, M. A. W., Frost, B. R., 2010. On the Controls of Oxygen Fugacity in the Generation and Crystallization of Peralkaline Melts. Journal of Petrology, 51(9): 1831-1847. https://doi.org/10.1093/petrology/egq040

Marks, M., Markl, G., 2001. Fractionation and Assimilation Processes in the Alkaline Augite Syenite Unit of the Ilímaussaq Intrusion, South Greenland, as Deduced from Phase Equilibria. Journal of Petrology, 42(10): 1947-1969. https://doi.org/10.1093/petrology/42.10.1947

Marks, M. A. W., Hettmann, K., Schilling, J., et al., 2011. The Mineralogical Diversity of Alkaline Igneous Rocks: Critical Factors for the Transition from Miaskitic to Agpaitic Phase Assemblages. Journal of Petrology, 52(3): 439-455. https://doi.org/10.1093/petrology/egq086

Marks, M. A. W., Markl, G., 2017. A Global Review on Agpaitic Rocks. Earth-Science Reviews, 173: 229-258. https://doi.org/10.1016/j.earscirev.2017.06.002

Martin, R. F., Whitley, J. E., Woolley, A. R., 1978. An Investigation of Rare-Earth Mobility: Fenitized Quartzites, Borralan Complex, N.W. Scotland. Contributions to Mineralogy and Petrology, 66(1): 69-73. https://doi.org/10.1007/bf00376086

McCuaig, T. C., Beresford, S., Hronsky, J., 2010. Translating the Mineral Systems Approach into an Effective Exploration Targeting System. Ore Geology Reviews, 38(3): 128-138. https://doi.org/10.1016/j.oregeorev.2010.05.008

McDonough, W. F., Sun, S. S., 1995. The Composition of the Earth. Chemical Geology, 120(3/4): 223-253. https://doi.org/10.1016/0009-2541(94)00140-4

McLemore, V. T., 2018. Rare Earth Elements (REE) Deposits Associated with Great Plain Margin Deposits (Alkaline-Related), Southwestern United States and Eastern Mexico. Resources, 7(1): 8. https://doi.org/10.3390/resources7010008

Meert, J. G., 2012. What's in a Name? The Columbia (Paleopangaea/Nuna) Supercontinent. Gondwana Research, 21(4): 987-993. https://doi.org/10.1016/j.gr.2011.12.002

Milani, L., Kinnaird, J. A., Lehmann, J., et al., 2015. Role of Crustal Contribution in the Early Stage of the Damara Orogen, Namibia: New Constraints from Combined $\mathrm{U}-\mathrm{Pb}$ and $\mathrm{Lu}-\mathrm{Hf}$ Isotopes from the Goas Magmatic Complex. Gondwana Research, 28(3): 961-986. https://doi.org/10.1016/j.gr.2014.08.007 
Miller, R. M., 2008. The Geology of Namibia. Ministry of Mines and Energy, Geological Survey of Namibia, Windhoek

Mitchell, R. H., 2005. Carbonatites and Carbonatites and Carbonatites. The Canadian Mineralogist, 43(6): 2049-2068. https://doi.org/10.2113/gscanmin.43.6.2049

Möller, V., Williams-Jones, A. E., 2016. Petrogenesis of the Nechalacho Layered Suite, Canada: Magmatic Evolution of a REE-Nb-Rich Nepheline Syenite Intrusion. Journal of Petrology, 57(2): 229-276. https://doi.org/10.1093/petrology/egw003

Mollo, S., Vona, A., 2014. The Geochemical Evolution of Clinopyroxene in the Roman Province: A Window on Decarbonation from Wall-Rocks to Magma. Lithos, 192-195: 1-7. https://doi.org/10.1016/j.lithos.2014.01.009

Moore, M., Chakhmouradian, A. R., Mariano, A. N., et al., 2015. Evolution of Rare-Earth Mineralization in the Bear Lodge Carbonatite, Wyoming: Mineralogical and Isotopic Evidence. Ore Geology Reviews, 64: 499-521. https://doi.org/10.1016/j.oregeorev.2014.03.015

Müntener, O., Kelemen, P. B., Grove, T. L., 2001. The Role of $\mathrm{H}_{2} \mathrm{O}$ during Crystallization of Primitive Arc Magmas under Uppermost Mantle Conditions and Genesis of Igneous Pyroxenites: An Experimental Study. Contributions to Mineralogy and Petrology, 141(6): 643-658. https://doi.org/10.1007/s004100100266

Nabyl, Z., Massuyeau, M., Gaillard, F., et al., 2020. A Window in the Course of Alkaline Magma Differentiation Conducive to Immiscible REE-Rich Carbonatites. Geochimica et Cosmochimica Acta, 282: 297-323. https://doi.org/10.1016/j.gca.2020.04.008

Nikiforov, A. V., Öztürk, H., Altuncu, S., et al., 2014. Kizilcaören Ore-Bearing Complex with Carbonatites (Northwestern Anatolia, Turkey): Formation Time and Mineralogy of Rocks. Geology of Ore Deposits, 56(1): 35-60. https://doi.org/10.1134/s107570151401005x

Nikiforov, A. V., Yarmolyuk, V. V., 2019. Late Mesozoic Carbonatite Provinces in Central Asia: Their Compositions, Sources and Genetic Settings. Gondwana Research, 69: 56-72. https://doi.org/10.1016/j.gr.2018.11.014

Nikolenko, A. M., Redina, A. A., Doroshkevich, A. G., et al., 2018. The Origin of Magnetite-Apatite Rocks of Mushgai-Khudag Complex, South Mongolia: Mineral Chemistry and Studies of Melt and Fluid Inclusions. Lithos, 320/321: 567-582. https://doi.org/10.1016/j.lithos.2018.08.030

Nikolenko, A. M., Doroshkevich, A. G., Ponomarchuk, A. V., et al., 2020. Ar-Ar Geochronology and Petrogenesis of the Mushgai-Khudag Alkaline-Carbonatite Complex (Southern Mongolia). Lithos, 372/373: 105675. https://doi.org/10.1016/j.lithos.2020.105675

Notholt, A., Highley, D., Harding, R., 1985. Investigation of Phosphate (Apatite) Potential of Loch Borralan Igneous Complex, Northwest Highlands, Scotland. Transactions of the Institution of Mining and Metallurgy, Section B, Applied Earth Science, 94: 58-65

Ntiharirizwa, S., Boulvais, P., Poujol, M., et al., 2018. Geology and $\mathrm{U}-\mathrm{Th}-\mathrm{Pb}$ Dating of the Gakara REE Deposit, Burundi. Minerals, 8(9): 394. https://doi.org/10.3390/min 8090394

O'Brien, H., Heilimo, E., Heino, P., 2015. The Archean Siilinjärvi Carbonatite Complex. Mineral Deposits of Finland. Elsevier, Amsterdam. 327-343. https://doi.org/10.1016/b978-0-12-410438-9.00013-3

Oh, C. W., Lee, B. C., Yi, S. B., et al., 2019. Correlation of Paleoproterozoic Igneous and Metamorphic Events of the Korean Peninsula and China; Its Implication to the Tectonics of Northeast Asia. Precambrian Research, 326: 344-362. https://doi.org/10.1016/j.precamres.2018.03.010

Öztürk, H., Altuncu, S., Hanilçi, N., et al., 2019. Rare Earth Element-Bearing Fluorite Deposits of Turkey: An Overview. Ore Geology Reviews, 105: 423-444. https://doi.org/10.1016/j.oregeorev.2018.12.021

Padilha, D. F., Bitencourt, M. D. F., Nardi, L. V. S., et al., 2019. Sources and Settings of Ediacaran Post-Collisional Syenite-Monzonite-Diorite Shoshonitic Magmatism from Southernmost Brazil. Lithos, 344/345: 482-503. https://doi.org/10.1016/j.lithos.2019.06.004

Parsons, I., 1965. The Feldspathic Syenites of the Loch Ailsh Intrusion, Assynt, Scotland. Journal of Petrology, 6(3): 365-394. https://doi.org/10.1093/petrology/6.3.365

Parsons, I., McKirdy, A. P., 1983. Inter-Relationship of Igneous Activity and Thrusting in Assynt: Excavations at Loch Borralan. Scottish Journal of Geology, 19(1): 59-66. https://doi.org/10.1144/sjg19010059

Peccerillo, A., 1992. Potassic and Ultrapotassic Rocks: Compositional Characteristics, Petrogenesis, and Geologic Significance. Episodes, 15(4): 243-251. https://doi.org/10.18814/epiiugs/1992/v15i4/002

Pehrsson, S. J., Eglington, B. M., Evans, D. A. D., et al., 2016. Metallogeny and Its Link to Orogenic Style during the Nuna Supercontinent Cycle. Geological Society, London, Special Publications, 424(1): 83-94. https://doi.org/10.1144/sp424.5

Peng, P., Zhai, M. G., Guo, J. H., et al., 2008. Petrogenesis of Triassic Post-Collisional Syenite Plutons in the Sino-Korean Craton: An Example from North Korea. Geological Magazine, 145(5): 637-647. https://doi.org/10.1017/s0016756808005037

Pilet, S., Baker, M. B., Stolper, E. M., 2008. Metasomatized Lithosphere and the Origin of Alkaline Lavas. Science, 320(5878): 916-919. https://doi.org/10.1126/science.1156563

Plank, T., 2014. The Chemical Composition of Subducting Sediments. In: Holland, H. D., Turekian, K. K., eds., Treatise on Geochemistry (Second Edition). Elsevier, Oxford. 607-629. https://doi.org/10.1016/b978-0-08-095975-7.00319-3

Poletti, J. E., Cottle, J. M., Hagen-Peter, G. A., et al., 2016. Petrochronological Constraints on the Origin of the Mountain Pass Ultrapotassic and Carbonatite Intrusive Suite, California. Journal of Petrology, 57(8): 1555-1598. https://doi.org/10.1093/petrology/egw050

Prelević, D., Akal, C., Foley, S. F., et al., 2012. Ultrapotassic Mafic Rocks as Geochemical Proxies for Post-Collisional Dynamics of Orogenic Lithospheric Mantle: The Case of Southwestern Anatolia, Turkey. Journal of Petrology, 53(5): 1019-1055. https://doi.org/10.1093/petrology/egs008

Prowatke, S., Klemme, S., 2005. Effect of Melt Composition on the Partitioning of Trace Elements between Titanite and Silicate Melt. Geochimica et Cosmochimica Acta, 69(3): 695-709. https://doi.org/10.1016/j.gca.2004.06.037

Richards, J. P., 2011. High Sr/Y Arc Magmas and Porphyry $\mathrm{Cu} \pm \mathrm{Mo} \pm \mathrm{Au}$ Deposits: Just Add Water. Economic Geology, 106(7): 1075-1081. https://doi.org/10.2113/econgeo.106.7.1075

Richards, J. P., Mumin, A. H., 2013. Magmatic-Hydrothermal Processes within an Evolving Earth: Iron Oxide-Copper-Gold and Porphyry $\mathrm{Cu} \pm \mathrm{Mo} \pm \mathrm{Au}$ Deposits. Geology, 41(7): 767-770. https://doi.org/10.1130/g34275.1

Richards, J. P., 2015. Tectonic, Magmatic, and Metallogenic Evolution of the Tethyan Orogen: From Subduction to Collision. Ore Geology Reviews, 70: 323-345. https://doi.org/10.1016/j.oregeorev.2014.11.009

Sarapää, O., Al-Ani, T., Lahti, S. I., et al., 2013. Rare Earth Exploration Potential in Finland. Journal of Geochemical Exploration, 133: 25-41. https://doi.org/10.1016/j.gexplo.2013.05.003

Sarıfakıŏlu, E., Özen, H., Hall, C., 2009. Petrogenesis of ExtensionRelated Alkaline Volcanism in Karaburhan (Sivrihisar-Eskisehir), NW Anatolia, Turkey. Journal of Asian Earth Sciences, 35(6): 502-515. https://doi.org/10.1016/j.jseaes.2009.03.002

Slezak, P., Spandler, C., Border, A., et al., 2021. Geology and Ore Genesis of the Carbonatite-Associated Yangibana REE District, Gascoyne Province, Western Australia. Mineralium Deposita, 56(5): 1007-1026. 
https://doi.org/10.1007/s00126-020-01026-z

Smith, M. P., Moore, K., Kavecsánszki, D., et al., 2016. From Mantle to Critical Zone: A Review of Large and Giant Sized Deposits of the Rare Earth Elements. Geoscience Frontiers, 7(3): 315-334. https://doi.org/10.1016/j.gsf.2015.12.006

Smithies, R. H., Marsh, J. S., 1998. The Marinkas Quellen Carbonatite Complex, Southern Namibia; Carbonatite Magmatism with an Uncontaminated Depleted Mantle Signature in a Continental Setting. Chemical Geology, 148(3/4): 201-212. https://doi.org/10.1016/s0009-2541(98)00029-1

Sokół, K., Halama, R., Meliksetian, K., et al., 2018. Alkaline Magmas in Zones of Continental Convergence: The Tezhsar Volcano-Intrusive Ring Complex, Armenia. Lithos, 320/321: 172-191. https://doi.org/10.1016/j.lithos.2018.08.028

Song, S. G., Wang, M. J., Wang, C., et al., 2015. Magmatism during Continental Collision, Subduction, Exhumation and Mountain Collapse in Collisional Orogenic Belts and Continental Net Growth: A Perspective. Science China Earth Sciences, 58(8): 1284-1304. https://doi.org/10.1007/s11430-015-5102-x

Spandler, C., Slezak, P., Nazari-Dehkordi, T., 2020. Tectonic Significance of Australian Rare Earth Element Deposits. Earth-Science Reviews, 207: 103219. https://doi.org/10.1016/j.earscirev.2020.103219

Stoppa, F., Schiazza, M., Rosatelli, G., et al., 2019. Italian Carbonatite System: From Mantle to Ore-Deposit. Ore Geology Reviews, 114: 103041. https://doi.org/10.1016/j.oregeorev.2019.103041

Stumpfl, E. F., Kirikoglu, M. S., 1985. Fluorite-Barite-Rare Earths Deposits at Kizilcaoren, Turkey. S. Mitt. Österr. Geol. Ges., 78: 193-200

Styles, M. T., Gunn, A. G., Rollin, K. E., 2004. A Preliminary Study of PGE in the Late Caledonian Loch Borralan and Loch Ailsh Alkaline Pyroxenite-Syenite Complexes, North-West Scotland. Mineralium Deposita, 39(2): 240-255. https://doi.org/10.1007/s00126-003-0404-x

Sylvester, P. J., 1989. Post-Collisional Alkaline Granites. The Journal of Geology, 97(3): 261-280. https://doi.org/10.1086/629302

Thi, N. T., Wada, H., Ishikawa, T., et al., 2014. Geochemistry and Petrogenesis of Carbonatites from South Nam Xe, Lai Chau Area, Northwest Vietnam. Mineralogy and Petrology, 108(3): 371-390. https://doi.org/10.1007/s00710-013-0301-7

Thirlwall, M. F., Burnard, P., 1990. Pb-Sr-Nd Isotope and Chemical Study of the Origin of Undersaturated and Oversaturated Shoshonitic Magmas from the Borralan Pluton, Assynt, NW Scotland. Journal of the Geological Society, 147(2): 259-269. https://doi.org/10.1144/gsjgs.147.2.0259

Thompson, R. N., Fowler, M. B., 1986. Subduction-Related Shoshonitic and Ultrapotassic Magmatism: A Study of Siluro-Ordovician Syenites from the Scottish Caledonides. Contributions to Mineralogy and Petrology, 94(4): 507-522. https://doi.org/10.1007/bf00376342

Tucker, R. D., Belkin, H. E., Schulz, K. J., et al., 2012. A Major Light Rare-Earth Element (Lree) Resource in the Khanneshin Carbonatite Complex, Southern Afghanistan. Economic Geology, 107(2): 197-208. https://doi.org/10.2113/econgeo.1f07.2.197

Vasyukova, O. V., Williams-Jones, A. E., 2019. Tracing the Evolution of a Fertile REE Granite by Modelling Amphibole-Melt Partitioning, the Strange Lake Story. Chemical Geology, 514: 79-89. https://doi.org/10.1016/j.chemgeo.2019.03.030

Veevers, J. J., 2007. Pan-Gondwanaland Post-Collisional Extension Marked by 650-500 Ma Alkaline Rocks and Carbonatites and Related Detrital Zircons: A Review. Earth-Science Reviews, 83(1/2): 1-47. https://doi.org/10.1016/j.earscirev.2007.03.001

Veksler, I. V., Petibon, C., Jenner, G. A., et al., 1998. Trace Element Partitioning in Immiscible Silicate-Carbonate Liquid Systems: An Initial Experimental
Study Using a Centrifuge Autoclave. Journal of Petrology, 39(11/12): 2095-2104. https://doi.org/10.1093/petroj/39.11-12.2095

Vigneresse, J. L., Ballouard, C., Liu, X., et al., 2021. Toward a Global Conceptual Model for Metal Enrichment in Felsic, Mafic-Ultramafic, and Alkaline-Carbonatitic Magmas. Ore Geology Reviews, 129: 103925. https://doi.org/10.1016/j.oregeorev.2020.103925

von Knorring, O., Clifford, T. N., 1960. On a Skarn Monazite Occurrence from the Namib Desert near Usakos, South-West Africa. Mineralogical Magazine and Journal of the Mineralogical Society, 32(251): 650-653. https://doi.org/10.1180/minmag.1960.032.251.06

Wall, F., Mariano, A. N., 1995. Rare Earth Minerals in Carbonatites: A Discussion Centred on the Kangankunde Carbonatite, Malawi. Mineralogical Society Series, 7: 193-226

Walsh, J. N., Buckley, F., Barker, J., 1981. The Simultaneous Determination of the Rare-Earth Elements in Rocks Using Inductively Coupled Plasma Source Spectrometry. Chemical Geology, 33(1/2/3/4): 141-153. https://doi.org/10.1016/0009-2541(81)90091-7

Walters, A. S., Goodenough, K. M., Hughes, H. S. R., et al., 2013. Enrichment of Rare Earth Elements during Magmatic and Post-Magmatic Processes: A Case Study from the Loch Loyal Syenite Complex, Northern Scotland. Contributions to Mineralogy and Petrology, 166(4): 1177-1202. https://doi.org/10.1007/s00410-013-0916-Z

Wang, D. H., Yang, J. M., Yan, S. H., et al., 2001. A Special Orogenic-Type Rare Earth Element Deposit in Maoniuping, Sichuan, China: Geology and Geochemistry. Resource Geology, 51(3): 177-188. https://doi.org/10.1111/j.1751-3928.2001.tb00090.x

Wang, T., Guo, L., Zhang, L., et al., 2015. Timing and Evolution of Jurassic-Cretaceous Granitoid Magmatisms in the Mongol-Okhotsk Belt and Adjacent Areas, NE Asia: Implications for Transition from Contractional Crustal Thickening to Extensional Thinning and Geodynamic Settings. Journal of Asian Earth Sciences, 97: 365-392. https://doi.org/10.1016/j.jseaes.2014.10.005

Weckmann, U., Ritter, O., Haak, V., 2003. A Magnetotelluric Study of the Damara Belt in Namibia: 2. MT Phases over $90^{\circ}$ Reveal the Internal Structure of the Waterberg Fault/Omaruru Lineament. Physics of the Earth and Planetary Interiors, 138(2): 91-112. https://doi.org/10.1016/s0031-9201(03)00079-7

Weller, O. M., St-Onge, M. R., 2017. Record of Modern-Style Plate Tectonics in the Palaeoproterozoic Trans-Hudson Orogen. Nature Geoscience, 10(4): 305-311. https://doi.org/10.1038/ngeo2904

Whalen, J. B., Wodicka, N., Taylor, B. E., et al., 2010. Cumberland Batholith, Trans-Hudson Orogen, Canada: Petrogenesis and Implications for Paleoproterozoic Crustal and Orogenic Processes. Lithos, 117(1/2/3/4): 99-118. https://doi.org/10.1016/j.lithos.2010.02.008

Whitney, D. L., Evans, B. W., 2010. Abbreviations for Names of Rock-Forming Minerals. American Mineralogist, 95(1): 185-187. https://doi.org/10.2138/am.2010.3371

Williams-Jones, A. E., Samson, I. M., Olivo, G. R., 2000. The Genesis of Hydrothermal Fluorite-REE Deposits in the Gallinas Mountains, New Mexico. Economic Geology, 95(2): 327-341. https://doi.org/10.2113/gsecongeo.95.2.327

Woodard, J., Hetherington, C. J., 2014. Carbonatite in a Post-Collisional Tectonic Setting: Geochronology and Emplacement Conditions at Naantali, SW Finland. Precambrian Research, 240: 94-107. https://doi.org/10.1016/j.precamres.2013.10.017

Woolley, A. R., Symes, R. F., Elliott, C. J., 1972. Metasomatized (Fenitized) Quartzites from the Borralan Complex, Scotland. Mineralogical Magazine, 38(299): 819-836. https://doi.org/10.1180/minmag.1972.038.299.06 
Woolley, A. R., 1970. The Structural Relationships of the Loch Borrolan Complex, Scotland. Geological Journal, 7(1): 171-182. https://doi.org/10.1002/gj.3350070110

Xie, Y. L., Li, Y. X., Hou, Z. Q., et al., 2015. A Model for Carbonatite Hosted REE Mineralisation-The Mianning-Dechang REE Belt, Western Sichuan Province, China. Ore Geology Reviews, 70: 595-612. https://doi.org/10.1016/j.oregeorev.2014.10.027

Xu, C., Huang, Z. L., Liu, C. Q., et al., 2003. Geochemistry of Carbonatites in Maoniuping REE Deposit, Sichuan Province, China. Science in China Series D: Earth Sciences, 46(3): 246-256. https://doi.org/10.1360/03yd9023

Xu, C., Campbell, I. H., Kynicky, J., et al., 2008. Comparison of the Daluxiang and Maoniuping Carbonatitic REE Deposits with Bayan Obo REE Deposit, China. Lithos, 106(1/2): 12-24. https://doi.org/10.1016/j.lithos.2008.06.005

Xu, C., Taylor, R. N., Li, W. B., et al., 2012. Comparison of Fluorite Geochemistry from REE Deposits in the Panxi Region and Bayan Obo, China. Journal of Asian Earth Sciences, 57: 76-89. https://doi.org/10.1016/j.jseaes.2012.06.007

Yang, Y. T., Guo, Z. X., Song, C. C., et al., 2015. A Short-Lived but Significant Mongol-Okhotsk Collisional Orogeny in Latest Jurassic-Earliest Cretaceous. Gondwana Research, 28(3): 1096-1116. https://doi.org/10.1016/j.gr.2014.09.010

Yasukawa, K., Nakamura, K., Fujinaga, K., et al., 2016. Tracking the Spatiotemporal Variations of Statistically Independent Components
Involving Enrichment of Rare-Earth Elements in Deep-Sea Sediments. Scientific Reports, 6: 29603. https://doi.org/10.1038/srep29603

Ying, Y. C., Chen, W., Lu, J., et al., 2017. In situ U-Th-Pb Ages of the Miaoya Carbonatite Complex in the South Qinling Orogenic Belt, Central China. Lithos, 290/291: 159-171. https://doi.org/10.1016/j.lithos.2017.08.003

Young, B. N., Parsons, I., Threadgould, R., 1994. Carbonatite near the Loch Borralan Intrusion, Assynt. Journal of the Geological Society, 151(6): 945-954. https://doi.org/10.1144/gsjgs.151.6.0945

Zanetti, A., Mazzucchelli, M., Rivalenti, G., et al., 1999. The Finero Phlogopite-Peridotite Massif: An Example of Subduction-Related Metasomatism. Contributions to Mineralogy and Petrology, 134(2/3): 107-122. https://doi.org/10.1007/s004100050472

Zheng, X., Liu, Y., 2019. Mechanisms of Element Precipitation in Carbonatite-Related Rare-Earth Element Deposits: Evidence from Fluid Inclusions in the Maoniuping Deposit, Sichuan Province, Southwestern China. Ore Geology Reviews, 107: 218-238. https://doi.org/10.1016/j.oregeorev.2019.02.021

Zhou, J. B., Wilde, S. A., Zhao, G. C., et al., 2018. Nature and Assembly of Microcontinental Blocks within the Paleo-Asian Ocean. Earth-Science Reviews, 186: 76-93. https://doi.org/10.1016/j.earscirev.2017.01.012

Zindler, A., Hart, S., 1986. Chemical Geodynamics. Annual Review of Earth and Planetary $\quad$ Sciences, $14(1)$ : 493-571. https://doi.org/10.1146/annurev.ea.14.050186.002425 